\title{
REPRODUCTIVE TOXICOLOGY Environmental exposures, fetal testis development and function: phthalates and beyond
}

\author{
Hui Li and Daniel J Spade® \\ Department of Pathology and Laboratory Medicine, Brown University, Providence, Rhode Island, USA
}

Correspondence should be addressed to D / Spade; Email: daniel_spade@brown.edu

This paper forms part of a special section on Reproductive toxicology. The guest editors for this section were Dr Adam Watkins (The University of Nottingham, UK) and Dr Aileen Keating (lowa State University, IA, USA).

\begin{abstract}
Fetal development of the mammalian testis relies on a series of interrelated cellular processes: commitment of somatic progenitor cells to Sertoli and Leydig cell fate, migration of endothelial cells and Sertoli cells, differentiation of germ cells, deposition of the basement membrane, and establishment of cell-cell contacts, including Sertoli-Sertoli and Sertoli-germ cell contacts. These processes are orchestrated by intracellular, endocrine, and paracrine signaling processes. Because of this complexity, testis development can be disrupted by a variety of environmental toxicants. The toxicity of phthalic acid esters (phthalates) on the fetal testis has been the subject of extensive research for two decades, and phthalates have become an archetypal fetal testis toxicant. Phthalates disrupt the seminiferous cord formation and maturation, Sertoli cell function, biosynthesis of testosterone in Leydig cells, and impair germ cell survival and development, producing characteristic multinucleated germ cells. However, the mechanisms responsible for these effects are not fully understood. This review describes current knowledge of the adverse effects of phthalates on the fetal testis and their associated windows of sensitivity, and compares and contrasts the mechanisms by which toxicants of current interest, bisphenol A and its replacements, analgesics, and perfluorinated alkyl substances, alter testicular developmental processes. Working toward a better understanding of the molecular mechanisms responsible for phthalate toxicity will be critical for understanding the long-term impacts of environmental chemicals and pharmaceuticals on human reproductive health.

Reproduction (2021) 162 F147-F167
\end{abstract}

\section{Introduction}

Mammalian fetal testis development relies on a remarkably intricate series of interrelated cellular division, migration, and differentiation processes, which are orchestrated by multiple endocrine, paracrine, and intracellular signaling pathways. As a result, the fetal testis is susceptible to injury resulting from exposure to a variety of environmental chemicals and pharmaceuticals. The bipotential gonad consists of somatic cells - a supporting cell lineage and a steroidogenic cell lineage, germ cells that have migrated from the allantois, and yolk sac-derived macrophages. In $X Y$ mice, the testis developmental program is initiated by transient expression of Sry on an embryonic day 11.5 (e11.5, also called gestational day 11 or GD 11) (Koopman et al. 1990), which leads to a persistent gene expression program that promotes the commitment of the supporting cell lineage to Sertoli cell fate and the eventual development of the testis (Lin \& Capel 2015). Sertoli cells continue to express Sertoli cell identity genes, including Sox9, Pdgfra, and NrOb1 (DAX1), throughout life (Brennan \& Capel 2004).

The commitment of undifferentiated supporting cells leads to the formation of seminiferous cords, the predecessors of the seminiferous tubules, comprised of Sertoli cells surrounding fetal germ cells (NelThemaat et al. 2011). Peritubular myoid cells (PTMCs) are recruited to the cords, and a basement membrane is established from collagens and laminins secreted by Sertoli cells and PTMCs (el Ouali et al. 1991, Virtanen etal. 1997). The Sertoli cell population is mitotically active throughout gestation, leading to elongation of cords. Germ cells, termed 'prospermatogonia,' meanwhile, mitotically expand prior to a quiescent period from e16.5 in the mouse (GD 18 in the rat) until birth, during when they differentiate and begin to display characteristics of spermatogonia (Culty 2013). Surrounding the cords is an interstitial compartment, containing Leydig cells, macrophages, connective tissue, and vasculature. The development of the testicular vasculature and seminiferous cords is simultaneous, promoted by VEGF 
secreted by macrophages, and PDGF from somatic cells at the testis-mesonephros boundary (Coveney et al. 2008, DeFalco et al. 2014). Fetal Leydig cells differentiate from the steroidogenic cell lineage between e11.5 and e13.5 in the mouse (Stevant et al. 2018). Once committed, fetal Leydig cells secrete testosterone and INSL3, which are responsible for masculinization of the reproductive tract and $\mathrm{AMH}$, which signals for regression of the Müllerian duct (Behringer 1995, Emmen et al. 2000).

The testis is susceptible to disruption by numerous toxicants, including pharmaceuticals, industrial and agricultural chemicals, and other environmental toxicants, such as heavy metals. Male reproductive toxicants are often classified by their target cell type. Germ cell toxicants produce direct germ cell death, which is a significant adverse effect, as the primary function of the testis is to maintain and support germ cells and produce mature spermatozoa. Germ cells, which are frequently dividing at many developmental stages and during spermatogenesis, can be directly targeted by, for example, DNA damage-inducing alkylating agents (Boekelheide 2005). Sertoli cell toxicants can also cause germ cell death indirectly, often through damage to the Sertoli cell cytoskeleton, which is the mechanism of the n-hexane metabolite, 2,5-hexanedione (Boekelheide 1988, Allard \& Boekelheide 1996). Apart from directly injuring germ cells or Sertoli cells, endocrine disruption represents a common mode of male reproductive toxicity. Endocrine-disrupting chemicals mimic hormones by binding to their receptors, inhibit the binding of endogenous hormones to their receptors, or alter the metabolic processes that control the quantity of hormone in circulation. Estrogenic compounds, such as diethylstilbestrol, and antiandrogens, such as vinclozolin, are well-characterized male reproductive toxicants in both the adult and fetal testis (Fielden et al. 2002, Hotchkiss et al. 2004, Gray et al. 2005, N'TumbaByn et al. 2012).

In the human health context, exposure to male reproductive toxicants and endocrine disruptors contributes to male factor infertility and other adverse health outcomes. The most straightforward examples are toxicant exposures during adulthood that result in disrupted spermatogenesis, potentially leading to infertility due to oligozoospermia, which can be transient or persistent. A classic example of this was discovered when a cohort of agricultural workers suffered irreversible infertility as a result of exposure to the nematocide, 1,2-dibromo-3-chloropropane (Whorton et al. 1977). As opposed to occupational exposure to testicular toxicants, understanding the long-term impact of gestational exposure to male reproductive toxicants presents a greater challenge for several reasons. First, typical levels of human exposure to environmental toxicants in the general population are much lower than the levels experienced by workers in industrial or occupational settings. Secondly, the latency of effects makes it difficult to test for causality between human exposures and outcomes and it is costly and time-consuming to design experiments in animals to test for later-life effects. Finally, testicular development is complex and still incompletely understood, which makes the discovery of toxicity mechanisms targeting fetal testis development a challenge. In spite of these difficulties, it has been hypothesized that environmental factors are contributing to increasing rates of adverse male reproductive health outcomes worldwide. These adverse outcomes, including infertility, testicular cancer, and congenital defects of the male reproductive tract, are hypothesized to share a common origin in disrupted fetal development, a phenomenon termed 'testicular dysgenesis syndrome' (Skakkebaek et al. 2001). For example, a report from a Danish cancer registry shows that testicular cancer rates have more than tripled between 1944 and 2009, rising to a rate of approximately 10 cases per 100,000 (Andersson et al. 2016). A recent meta-analysis of global sperm counts, similarly, showed a significant negative trend over time from 1973 to 2011, regardless of whether the populations were known to be fertile or unselected for fertility (Levine et al. 2017). Declining sperm count may contribute to infertility, which is experienced by approximately $12 \%$ of couples attempting to achieve pregnancy (Mehta et al. 2016). Hypospadias and cryptorchid testis, meanwhile, are two of the most commonly diagnosed birth defects in males, and there is some evidence that rates are increasing (Toppari et al. 2001). Despite this evidence of increases in TDS outcomes, the causality of environmental exposures has not been definitively supported.

Phthalic acid esters (phthalates) are an environmental exposure of concern for male reproductive health, which provide an excellent illustration of how susceptible many of the cellular and biochemical processes in testis development are to disruption (Fig. 1) and which may provide a model for TDS. Phthalates disrupt spatial patterning of cells during testis development, causing a histological phenotype termed 'testicular dysgenesis'. The combination of antiandrogenic effects and dysgenesis in animals results in immediate and later-life defects in testicular function and male reproductive tract development, a phenomenon termed 'phthalate syndrome,' which has been proposed as a model of TDS in humans. Despite this profound toxicity, the mechanisms underlying the response still remain unclear. Phthalate toxicity is likely the result of multiple injuries to the fetal Sertoli and Leydig cells. It may be initiated by disruption to androgen signaling, INSL3 signaling, and/or additional nuclear receptors, such as peroxisome proliferator-activated receptors (PPARs) and retinoic acid receptors (RARs). The goals of this review are to demonstrate the sensitivity of fetal testis development to environmental insults by reviewing the current knowledge of phthalate toxicity mechanisms and the remaining knowledge gaps, review trends in 


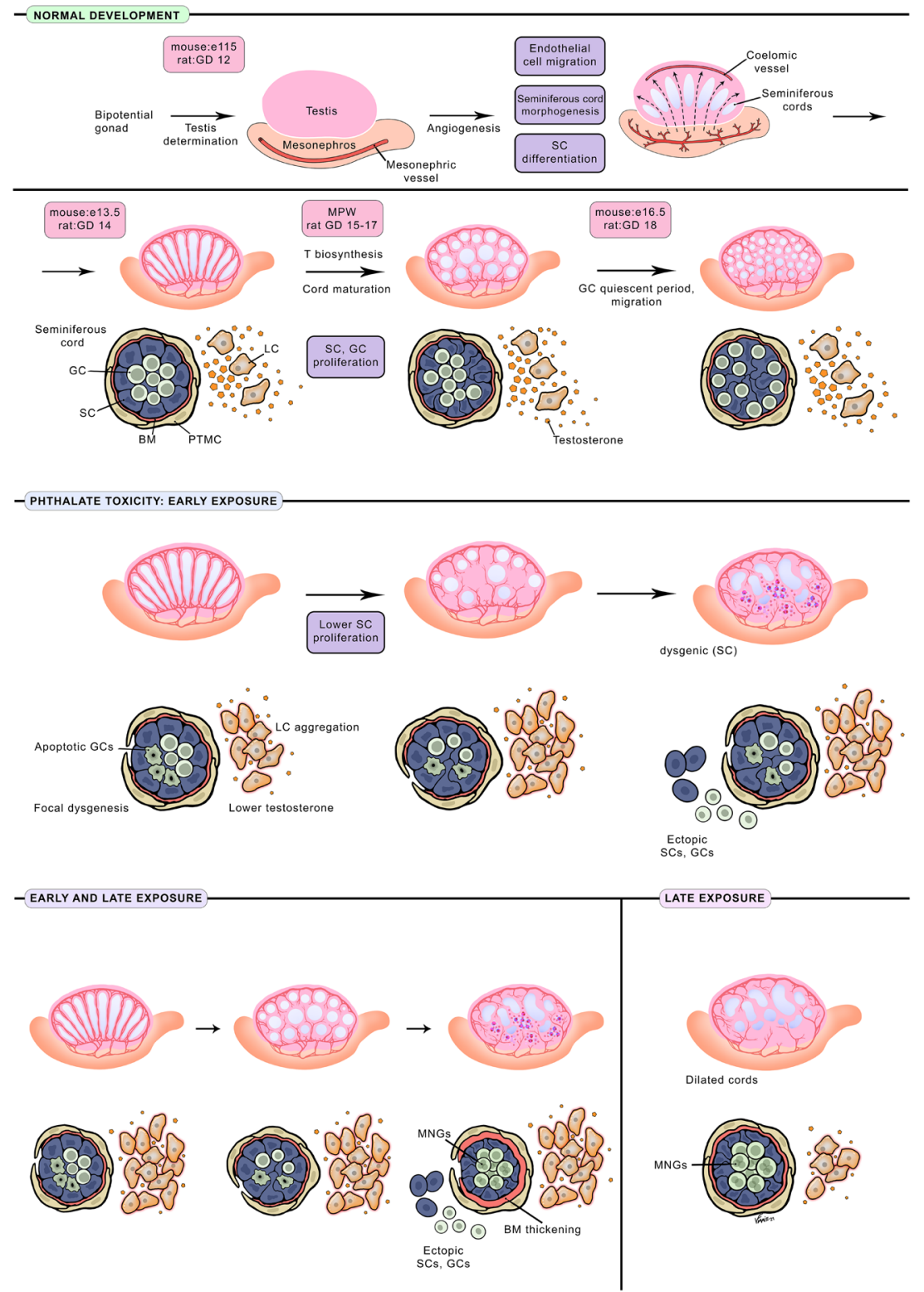

Figure 1 Normal rodent testis development and effects of fetal phthalate exposure in rats and mice. Fetal testis development, depicted in the top two panels, begins with the determination of the indifferent gonad on embryonic day 11.5 (e11.5) in the mouse or gestational day (GD) 12 in the rat. Supporting cells commit to Sertoli cell (SC) fate, which initiates the formation of seminiferous cords. Angiogenesis occurs simultaneously, relying on endothelial cells that migrate from the mesonephros, and steroidogenic cells commit to Leydig cell (LC) fate. Seminiferous cord maturation continues with recruitment of peritubular myoid cells (PTMCs), deposition of basement membrane (BM), and proliferation of SCs, giving rise to longer, convoluted cords. Germ cells (GCs), which are termed 'prospermatogonia,' proliferate until e16.5 (mouse) or GD 18 (rat), at which point they enter a quiescent phase and differentiate, taking on some characteristics of spermatogonia, reviewed in (Culty 2009). LCs produce testosterone, INSL3, and anti-Müllerian hormone throughout the fetal period. The critical window during which these hormones are responsible for masculinization of the male reproductive tract, termed the 'masculinization programming window' (MPW), spans approximately GD 15-17 in the rat (Welsh et al. 2008). Phthalate toxicity, as depicted in the lower two panels, has been well characterized in the fetal rat testis, in which the different phases of testis development create unique windows of sensitivity for phthalates. Only in rats, gestational phthalate exposure reduces testosterone (illustrated here as orange particles emanating from Leydig cells), regardless of the exposure timing. However, exposure during the MPW (early exposure, above) leads to the most significant adverse outcomes on masculinization of the reproductive tract, such as undescended testis and hypospadias. Similarly, dysgenesis of seminiferous cords is reportedly greatest when exposure occurs during the MPW, leading to incomplete or ruptured cords, ectopic GCs and SCs, and clustering of LCs (Lara et al. 2017, van den Driesche et al. 2017). This early exposure window is also associated with increased germ cell death in the fetal mouse (Lehraiki et al. 2009). Late gestational phthalate exposure, defined as exposure beginning after the GC quiescent period on GD 18 in the rat, results in inhibition of SC proliferation, induces multinucleated germ cells (MNGs), germ cell clustering, dilated cords, and thickening of the BM (Boekelheide et al. 2009, Spade et al. 2015). The exposure that continues throughout the early and late windows results in a combination of these effects, though with less prevalent dysgenic areas (Lara et al. 2017). All of these effects may contribute to reduced later-life fertility following exposure to male reproductive toxicants during fetal development. 
the recent experimental literature (2010-2020) on fetal testis toxicant effects from rodent and human tissue models, and summarize evidence that disrupted fetal testis development leads to impaired later-life male reproductive function.

\section{Search methodology, results, and scope of review}

We identified manuscripts for this review by searching PubMed between August 10, 2020, and April 16, 2021 (Supplementary Table 1, see section on supplementary materials given at the end of this article). To determine the overall volume of published literature on fetal testis toxicants, we performed an initial search for '(toxic OR toxicant OR toxicity) AND (fetal OR gestational) AND (testis OR testicular),' which returned 1745 results published since 1964, with a significant increase in publication rate during the 1990s leading to an average of 50.5 papers per year since 2010 (excluding the partial year 2021). Based on our initial search, we determined that the classes of compounds most frequently investigated for fetal testicular toxicity in recent years were phthalates, bisphenol A, analgesics and/or NSAIDS, and perfluoroalkyl substances (PFAS). Thus, in subsequent searches, we added the terms '(phthalate OR phthalates),' '('bisphenol A' OR BPA OR bisphenols)'; '(analgesic OR NSAID)'; and '(PFAS OR 'perfluorinated alkyl substances' OR PFOA OR PFOS).' We limited the searches by automatically excluding any papers indexed as 'review' or 'critical review' on PubMed. Subsequently, we manually reviewed the results and excluded any additional review or commentary articles, epidemiology publications, articles in which the exposure window did not include gestation, articles that used only cell culture models, articles that did not include experimental data on the class of compounds in question, and articles for which the full text could not be retrieved.

Our searches returned 389 results pertaining to phthalates, spanning the years 1982 to 2021, almost all published from 2000 to the present, and 154, 94, and 18 results pertaining to bisphenol $\mathrm{A}$, analgesics, and PFAS, respectively, comprising 31.0, $14.9,4.7$, and $2.8 \%$ of results since 2010, respectively (Supplementary Tables 1,2 and 3). After manual exclusion, the totals were 99, 47,12 , and 8 papers per class, respectively. We did not seek to comprehensively review the 166 papers that met our search and exclusion criteria. Rather, based on the prevalence of papers in these categories, we focused this review on the current knowledge and knowledge gaps in the fetal testis toxicity of phthalates, and we reviewed the literature on bisphenol A, analgesic drugs, and perfluorinated compounds to make comparisons about known mechanisms of fetal testis toxicity. Given space restraints, we did not attempt to review the epidemiology literature on fetal testis toxicants, the kinetics of most compounds, or the reproductive toxic effects on nontestis organs, such as the prostate or placenta. Where possible, we have cited prior reviews that address those topics.

\section{Phthalates}

Phthalates are the most widely studied class of fetal male reproductive toxicants. Despite intense interest in fetal testis toxicity of phthalates for two decades, the mechanisms remain incompletely understood. Several recent papers describe the major knowledge gap in phthalate toxicity research by applying the adverse outcome pathway (AOP) paradigm, a conceptual framework that links toxicants to adverse (toxic) outcomes through a 'molecular initiating event (MIE)' and subsequent 'key events,' usually cellular processes that mediate the toxic response (Ankley et al. 2010, OECD 2018). Hypothesized AOPs to describe phthalates' antiandrogenic mode of action illustrate that there is no known MIE for phthalate toxicity in the fetal testis (Howdeshell et al. 2015, Conley et al. 2018, Arzuaga et al. 2019, Clewell et al. 2020, Gray et al. 2020). In spite of this knowledge gap, it is well known that phthalates alter testicular morphology, survival, and differentiation of germ cells in all species studied to date and disrupt endocrine functions in the rat fetal testis. This illustrates both the unique susceptibility of the fetal testis to environmental toxicants and the remaining work that will be required to understand this susceptibility in its entirety.

\section{Reduced testosterone biosynthesis}

Phthalate diesters are metabolized to toxicologically active monoesters by intestinal and liver lipases (Albro 1986) and are transported across the placenta (Struve et al. 2009). Synthesis of testosterone in fetal Leydig cells is diminished by phthalates, especially in the rat (Gray et al. 2000, Parks et al. 2000, Mylchreest et al. 2002), but phthalates do not antagonize the androgen receptor (Parks et al. 2000, Stroheker et al. 2005). All ortho-phthalic acid esters in which the major aliphatic side chains are between four and six carbons in length reduce testosterone in this way, as do some with longer aliphatic or cyclic side chains; the lowest in vivo dose at which a phthalate has been reported to significantly reduce testosterone is $33 \mathrm{mg} / \mathrm{kg} /$ day dipentyl phthalate (DPeP) (Table 1) (Furr et al. 2014). The loss of testosterone leads to reduced masculinization of the male reproductive tract and loss of masculine secondary sex characteristics in rats. This phenomenon, termed 'phthalate syndrome,' results in hypospadias, undescended testis, retained nipples, and decreased anogenital distance (AGD) (Foster 2006). The testis has an abdominal descent phase driven by INSL3 and a scrotal descent phase driven by testosterone. Both of these signals are reduced by phthalate exposure, impairing testis descent (Shono et al. 2000, Wilson et al. 2004). This has been considered a 


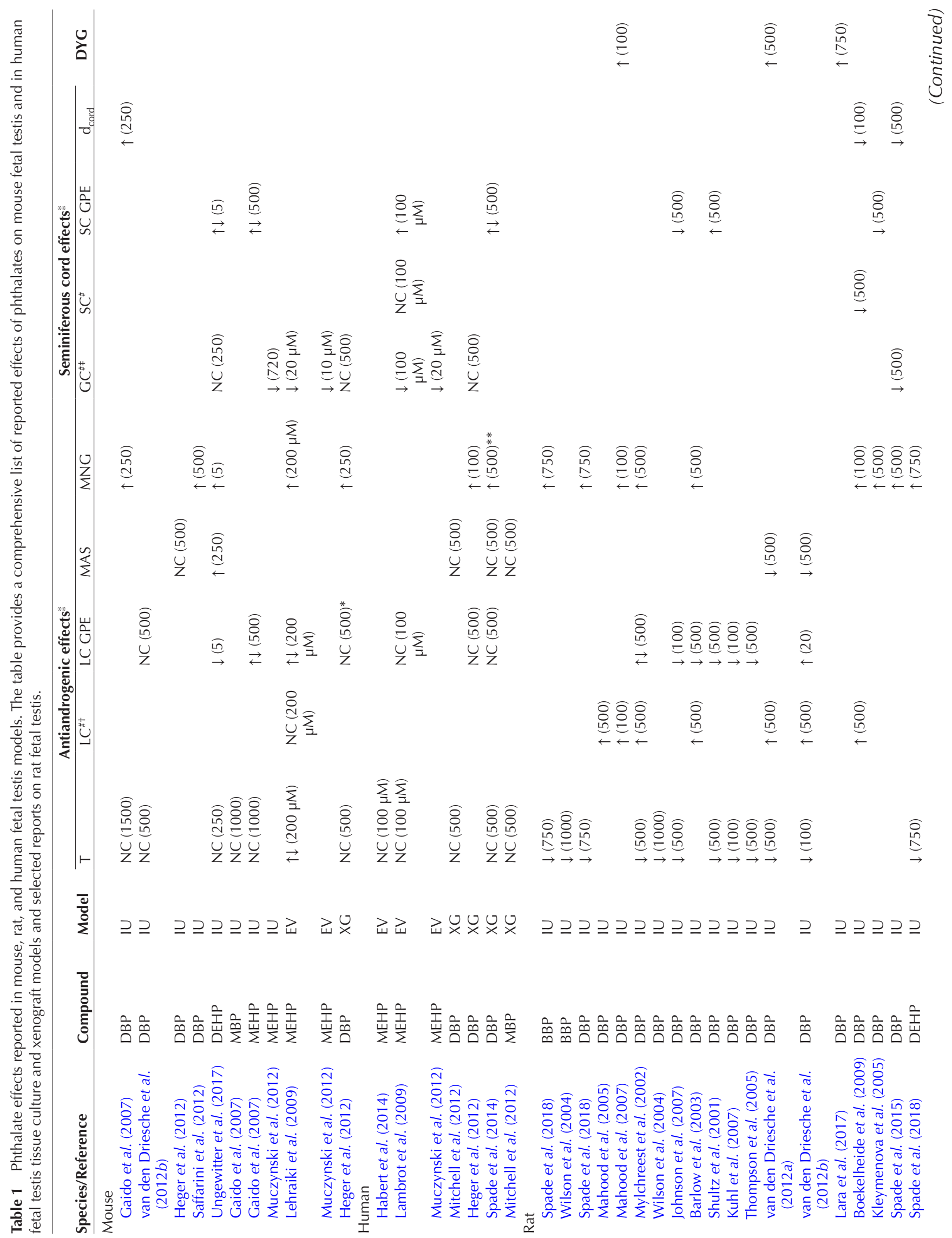




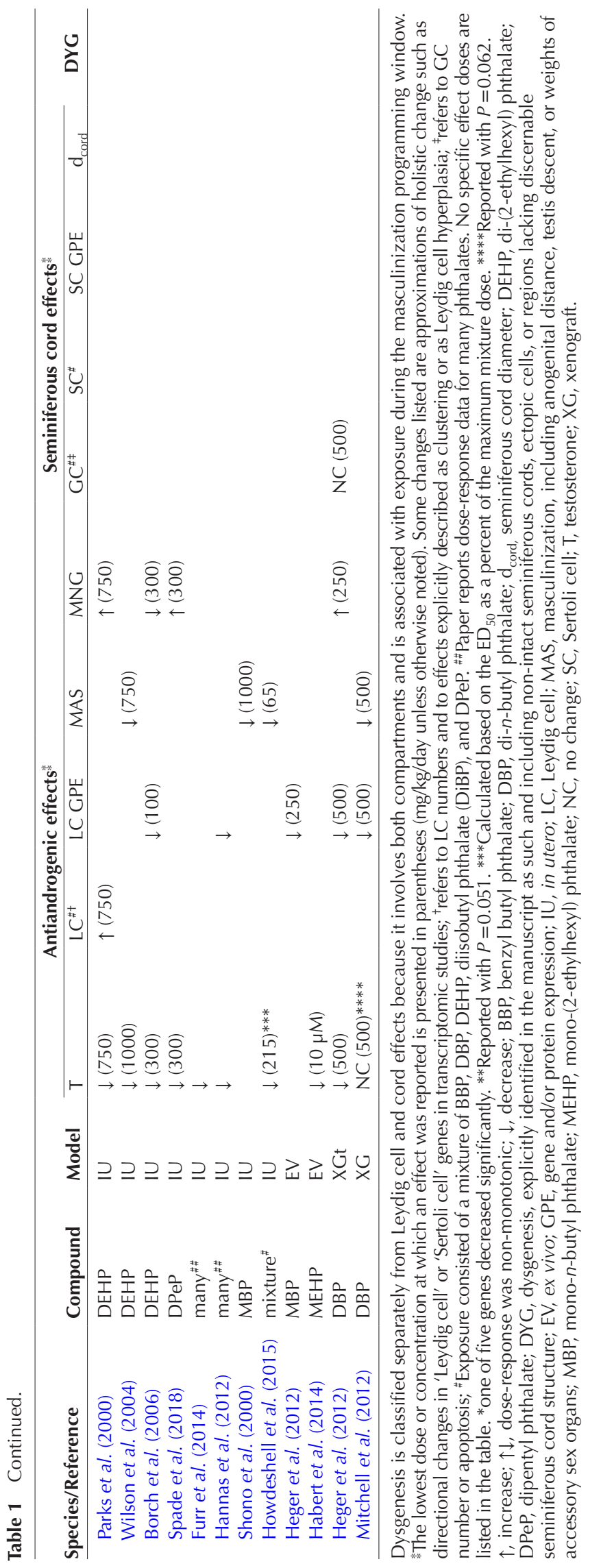

model for 'testicular dysgenesis syndrome' in humans, which consists of undescended testes, hypospadias, decreased male fertility, and increased testicular cancer risk (Skakkebaek et al. 2001).

The mechanism through which phthalates decrease testicular testosterone is not understood. Phthalates bind and activate PPARs in other tissues, but there is no evidence that phthalates enhance the expression of PPAR $\alpha$ target genes in the fetal testis (Hannas et al. 2012). The loss of testicular testosterone occurs in part through decreased expression of genes and proteins involved in steroid hormone biosynthesis, including Cyp11a1, Cyp17a1, Hsd3b1, Hsd17b1, Scarb1, and Star (Shultz et al. 2001, Barlow et al. 2003, Johnson et al. 2007, Hannas et al. 2012). Some of the phthalate-driven gene expression changes are dependent on inhibition of CEBP $\beta$ and possibly SF-1 (Borch et al. 2006, Kuhl et al. 2007) or prolonged expression of COUP-TFII (van den Driesche et al. 2012b). However, phthalates also cause a rapid decline in testosterone within $1 \mathrm{~h}$ of a single in utero phthalate exposure (Thompson et al. 2005), suggesting that a fairly rapid biochemical mechanism initiates this effect. Phthalate-driven decreases in testosterone also coincide with changes in Leydig cell biology, including Leydig cell clustering, hyperplasia, and intraseminiferous cord fetal Leydig cells (Mylchreest et al. 2002, Mahood et al. 2005).

\section{Species differences}

Although the effect of phthalates on testosterone biosynthesis is well characterized in the fetal rat, there are differences in the reported responses of rat, mouse, nonhuman primate, and human fetal testes to phthalates, especially with regard to testosterone suppression (Johnson et al. 2012, Habert et al. 2014) (Table 1). Several in utero exposure studies have reported that the mouse fetal testis is insensitive to the antiandrogenic effects of certain phthalates that are known to reduce testosterone in the rat, specifically di-n-butyl phthalate (DBP), monon-butyl phthalate (MBP), and mono-(2-ethylhexyl) phthalate (MEHP) at doses as high as $1500 \mathrm{mg} / \mathrm{kg} /$ day DBP (Gaido et al. 2007, Heger et al. 2012, van den Driesche et al. 2012b, Ungewitter et al. 2017). However, those same phthalates induce multinucleated germ cells (MNGs), increase seminiferous cord diameter, and alter Sertoli cell gene expression in mice, as they do in rats (Gaido et al. 2007, Saffarini et al. 2012, Ungewitter et al. 2017). MNGs have not been quantified in as many publications as effects on testosterone, but they have been induced significantly at doses as low as $100 \mathrm{mg} / \mathrm{kg} /$ day DBP in the rat (Boekelheide et al. 2009) and $250 \mathrm{mg} /$ $\mathrm{kg}$ /day in mouse fetal testis xenografts (Heger et al. 2012) and have been observed but not quantified at doses as low as $5 \mathrm{mg} / \mathrm{kg} /$ day in the mouse (Ungewitter et al. 2017). This distinction between what we will term 'antiandrogenic effects' and 'seminiferous cord effects' 
of phthalates has been supported by ex vivo mouse testis culture experiments, in which phthalate exposure has been reported to reduce germ cell number or increase MNGs, while effects on testosterone were equivocal in one experiment. Specifically, MEHP exposure with or without $\mathrm{LH}$ stimulation led to increased testosterone in e 13.5 testis cultures. In e 18.5 cultures, MEHP exposure with no LH stimulation increased testosterone, but with LH or CAMP stimulation, MEHP reduced testosterone (Lehraiki et al. 2009, Muczynski et al. 2012). Likewise, in a xenotransplant experiment, DBP increased MNGs in mouse fetal testes grafted into mouse hosts but had no effect on testosterone or host anogenital distance, a secondary sex characteristic used as a measure of testosterone-driven developmental masculinization (Heger et al. 2012). Few nonhuman primate studies of phthalate toxicity have been reported. Exposure of fetal marmosets to $500 \mathrm{mg} / \mathrm{kg} /$ day MBP resulted in sporadic germ cell clustering but no other effects on testicular histology and no changes in testosterone (McKinnell et al. 2009), while the same dose suppressed testosterone biosynthesis and induced Leydig cell hyperplasia in neonatal marmosets (Hallmark et al. 2007).

Similar to the mouse and nonhuman primate, the human fetal testis is insensitive to the testosteronereducing effect of phthalates. This has been demonstrated by three human fetal testis xenotransplant experiments under slightly different experimental conditions (Heger et al. 2012, Mitchell et al. 2012, Spade et al. 2014) (Table 1). First, human fetal testis tissue subcutaneously xenografted into immunosuppressed mice showed no significant reduction in testosterone or secondary sex characteristics following exposure to DBP or MBP, with concurrent hCG stimulation (Mitchell et al. 2012). In a separate experiment, the same research group has shown that DBP exposure results in germ cell clustering, altered germ cell-Sertoli cell contacts, and induction of MNGs in xenografted human fetal testis tissue (van den Driesche et al. 2015). Secondly, in a study of human fetal testes xenografted into the renal subcapsular space of immunosuppressed rats, DBP caused an increase in MNGs but no change in expression of genes required for steroidogenesis (Heger et al. 2012). Finally, we used a model in which human fetal testis tissue was grafted into the renal subcapsular space of an hCGstimulated, castrate, athymic nude mouse host to test whether suppression of testosterone was related to phthalate exposure or sufficient to cause induction of MNGs. We found that DBP did not reduce testosterone, and that the reduction of testosterone caused by the CYP17A1 inhibitor, abiraterone, did not induce MNGs, further demonstrating that testosterone reduction and histopathology caused by phthalates are independent effects (Spade et al. 2014). This lack of phthalate effects on testosterone biosynthesis has also been corroborated by evidence from ex vivo human fetal testis culture experiments (Lambrot et al. 2009, Muczynski et al. 2012,
Habert et al. 2014). To date, there has been no direct evidence from any experimental model that phthalates reduce testosterone biosynthesis in human fetal testis tissue. There are some notable limitations to these models. Human fetal testis exposure experiments often have smaller sample sizes than in utero rodent exposure models, and the gestational age range is limited to tissue from pre-viable fetal losses. Ideally, these experiments should be replicated further with varied exposure timing and dose. It is impossible to rule out the possibility that some phthalate compound at some exposure level would have an antiandrogenic effect at some gestational time point. However, the combination of xenograft and ex vivo culture models performed by different research groups, under different conditions, combined with the comparison of DBP with abiraterone as a positive control antiandrogen, gives high confidence that the human fetal testis is either quantitatively less sensitive or categorically insensitive to the antiandrogenic effects of phthalates.

This species difference raises the question of how to interpret the antiandrogenic effects of phthalates on the rat fetal testis in the context of human health. At least two factors are important to consider: the linkage between antiandrogenic and seminiferous cord effects of phthalates in the rat, and the epidemiologic evidence of androgen-related phthalate effects in humans. In the human and mouse studies that found the fetal testis to be insensitive to phthalate antiandrogenic effects, the phthalates nonetheless caused adverse effects on the development of the testis, including changes in seminiferous cord development, Sertoli cell function, germ cell death, and multinucleation of germ cells, which are described below. In other words, in all experimental systems that have been tested, phthalate exposures result in adverse seminiferous cord effects. This is likely to mean that the most directly relevant endpoints for human health are the seminiferous cord effects. On the other hand, antiandrogenic effects in the rat are clearly linked to seminiferous cord effects. We have demonstrated that in the rat model, there is a high degree of concordance of effects within a particular phthalate molecule, between the antiandrogenic effects and histological alterations in the seminiferous cord. In other words, phthalates, such as di-(2-ethylhexyl) phthalate (DEHP), DBP, benzyl butyl phthalate (BBP), and DPeP, cause both a reduction in testosterone and altered germ cell and seminiferous cord morphology in the fetal rat testis, while shorter chain phthalates, such as dimethyl phthalate (DMP) and diethyl phthalate (DEP), para-phthalic acid diesters, such as dioctyl terephthalate (DOTP), and a brominated phthalate cause neither effect (Spade et al. 2018). This suggests that phthalate toxicity is organized by upstream regulatory mechanisms that are consistent across species. This is an unproven hypothesis, but a similar dose-response for antiandrogenic and seminiferous cord effects of phthalates in the rat would indicate that reduced fetal testosterone is a biomarker 
of phthalate effect that is relevant to human health risk assessment.

A second point is that some male reproductive system outcomes related to inhibition of androgen signaling are associated with maternal urinary phthalate metabolites or other measures of gestational phthalate exposure in epidemiological studies of humans. These findings include associations between human maternal urinary phthalate metabolites and anogenital distance, cryptorchid testis, and hypospadias (Bornehag et al. 2015, Radke et al. 2018). Some of these associations have been supported by critical reviews, such as the relationship between gestational DEHP exposure and reduced anogenital distance (Dorman et al. 2018). This is difficult to reconcile with the lack of evidence for this effect in the experimental literature. However, it is notable that this species difference only applies to fetal exposures, as postnatal phthalate exposures are antiandrogenic in humans (Albert \& Jegou 2014).

\section{Testicular dysgenesis maldevelopment of testicular structures}

The fetal testis alterations caused by phthalates have been referred to as 'testicular dysgenesis,' not to be confused with testicular dysgenesis syndrome. Testicular dysgenesis consists of malformed tubules, Leydig cell clustering, intratubular Leydig cells, germ cell death, and induction of MNGs (Mahood et al. 2006, 2007) (Fig. 1). Testicular dysgenesis may be most severe when treatment is initiated after cord formation and during the masculinization programming window (MPW) (van den Driesche et al. 2012a, Lara et al. 2017), but there are several, potentially distinct, windows of sensitivity for histopathologic effects of phthalates. Phthalates impair Sertoli cell proliferation when treatment begins on GD 12, leading to a reduced number of seminiferous cord cross-sections and increased cross-sectional diameter in testicular sections taken during later gestation. This likely indicates impairment of the processes required for testis cords to elongate and convolute. Phthalate exposure also alters the cytoskeleton of Sertoli cells, leading to a loss of contact between Sertoli and germ cells, which may contribute to the phenotype of germ cell clustering (Kleymenova et al. 2005, Boekelheide et al. 2009). In later gestation, only from GD 18 onward in the rat, phthalate exposure leads to the production of MNGs, not through nuclear division without cytokinesis but presumably through fusion or collapse of germ cell clones that are connected by intercellular bridges (Ferrara et al. 2006, Spade et al. 2015). This window of sensitivity corresponds with the quiescent period of germ cell development (Culty 2013). Additionally, phthalate effects on PTMCs may contribute to testicular dysgenesis, as phthalate exposure leads to thickening of the seminiferous cord basement membrane, assessed in late gestation (Veeramachaneni \& Klinefelter 2014).

\section{Possible molecular targets}

Given that the histopathological effects of phthalates are consistent across species and do not rely on testosterone levels, a critical question is what upstream molecular initiating events could be responsible for phthalate toxicity. Phthalates bind peroxisome PPARs, and PPAR activation is responsible for phthalate toxicity in some tissues, such as the liver; however, PPARA is not required for phthalate-driven testosterone reduction, and phthalates do not induce a typical PPAR-mediated signaling response (Gazouli et al. 2002, Corton \& Lapinskas 2004, Hannas et al. 2012). Phthalates antagonize cholesterol biosynthesis (Thompson et al. 2004), and the cholesterol-reducing drug, simvastatin, exacerbates phthalate effects on testosterone (Beverly et al. 2014). Dexamethasone also enhances phthalate toxicity, suggesting glucocorticoid receptor signaling as a possible mechanism (Drake et al. 2009). Phthalate exposure causes elevated plasma estradiol and gene expression patterns similar to estrogen receptor activation (Klinefelter et al. 2012, Veeramachaneni \& Klinefelter 2014), and the soy estrogen, genistein, alters phthalate toxicity, possibly through effects on testicular macrophages, a little-explored area of fetal testis toxicity (Jones et al. 2015, Walker et al. 2020).

Given the number of nuclear receptor signaling pathways thatare potentiallyaltered by phthalates, wehave hypothesized that there is a role of PPAR binding in fetal testicular phthalate toxicity, which may mediate adverse effects through crosstalk with other nuclear receptor signaling pathways. In fact, it has been demonstrated that MEHP has a cell type-specific effect on RAR signaling in mouse Sertoli cells, caused by PPAR-RAR competition for heterodimerization with retinoid $X$ receptors (RXRs) (Dufour et al. 2003). Control of RAR signaling is critical for the development and function of the testis. We have shown that phthalates interact with exogenous retinoic acid in the fetal testis, modulating the effects of retinoic acid on cord development (Spade et al. 2019b). This hypothesis is consistent with the effects of phthalates on the regulation of genes and proteins involved in the specification of the supporting cell lineage to granulosa or Sertoli-like phenotypes (Wang et al. 2015, Spade et al. 2019a). Clearly, phthalates alter the function of multiple nuclear receptor signaling pathways that are critical for normal testis development. However, the search for a definitive set of molecular initiating events of phthalate toxicity continues.

\section{Mechanistic clues in other classes of toxicants}

Although phthalate toxicity presents a complicated case that occurs through multiple mechanisms and is not 
fully described by classification as endocrine disruption, the effects of endocrine-disrupting chemicals (EDCs) mostly estrogens and antiandrogens - on the fetal testis have been the subject of a great deal of research, and the effects of these compounds may prove relevant as comparisons for phthalates. Several excellent reviews describe the impacts of antiandrogens that disrupt fetal testis development and function by reducing testosterone (e.g. ketoconazole, prochloraz, statins, phthalates), antagonizing the androgen receptor (e.g. procymidone, DDT), or through both mechanisms (e.g. linuron, prochloraz) (Gray et al. 2001, Wilson et al. 2008, Scott et al. 2009). It is well established that there is a sensitive window for antiandrogenic effects on the masculinization of the male reproductive tract, termed the 'masculinization programming window' (MPW), and that antiandrogens have their most significant effects on male reproductive system development during the MPW, as described in the recent review from Sharpe (2020). While the exact mechanism of estrogenic toxicity in the fetal testis is not as well characterized as the antiandrogens, environmental estrogens also exert toxic effects on fetal testis development, which has been previously reviewed (Scott et al. 2009) and which may be attributable to the balance between androgen and estrogen levels. Diethylstilbestrol is a classic estrogenic fetal testis toxicant (Fielden et al. 2002). For a detailed description of these mechanisms, we refer the reader to the review papers cited here. Presently, we will discuss two endocrine-disrupting exposures that have received significant attention within the last decade: bisphenol A and analgesic medications.

\section{An environmental estrogen bisphenol $A$ and replacements}

Bisphenol A (BPA), which was first commercially used in 1957, is one of the most highly produced chemicals worldwide and is used in numerous consumer products, such as plastic food and beverage containers, can linings, dental sealants, computers, and thermal paper. In almost all humans, BPA can be detected in the blood, urine, saliva, and other bodily fluids (Ikezuki et al. 2002, Sasaki et al. 2005). BPA is a controversial environmental exposure, due to its known estrogenic activity, on one hand, and its rapid metabolic clearance, on the other. Toxicokinetic studies of BPA in rodents have supported the argument that BPA is rapidly glucuronidated, and free BPA levels following oral exposure are very low (Doerge et al. 2010). Accordingly, the United States Food and Drug Administration (FDA) has maintained that BPA is safe as currently used. However, BPA can be transported across the placenta (Balakrishnan et al. 2010), and estrogenic compounds have demonstrated toxicity in the fetal testis. BPA has been identified as a modulator for both estrogen receptor alpha (ESR1/
$E R \alpha)$ and beta (ESR2/ER $\beta$ ) (Delfosse et al. 2012). At high concentrations in vitro, BPA can also bind to many other nuclear receptors, including the aryl hydrocarbon receptor (AHR), PPARs, AR, both thyroid hormone receptors (THRs), the pregnane $X$ receptor (NR1 I2/PXR), and estrogen-related receptor gamma (ESRRG/ERRg) (Moriyama et al. 2002, Matsushima et al. 2008, MolinaMolina et al. 2013). Collectively, by interacting with a variety of nuclear receptors, BPA can exert a profound impact on hormonal homeostasis.

Reports on the impact of BPA exposure on male reproductive development have varied widely. A recent review found a lack of consensus regarding the effect of BPA on fetal testis development, which may be attributed to differences in exposure protocol, animal models, BPA concentration range, and dosing time frame (Williams et al. 2014). In one recent publication, high-dose BPA exposure $(5$ or $50 \mathrm{mg} / \mathrm{kg}$ ) in mice resulted in decreased Sertoli cell number, altered expression of Sertoli cell-related genes, disruption of spermatogenesis, impaired epididymal sperm counts, altered morphology, and reduced motility at postnatal week 6 (Tainaka et al. 2012). Another study of high-dose BPA in the fetal rat $(0,4,40$, and $400 \mathrm{mg} / \mathrm{kg}$ body weight) reported a dosedependent decrease in serum testosterone level in male fetuses, only at 40 and $400 \mathrm{mg} / \mathrm{kg}$ compared to control. On GD 21, fetal Leydig cell number, but not Sertoli cell number, was reduced in the $400 \mathrm{mg} / \mathrm{kg}$ group, and expression of Leydig cell and Sertoli cell markers was reduced (Lv et al. 2019). Although this indicates that doses of $40 \mathrm{mg} / \mathrm{kg} /$ day and above could potentially disrupt the development of the male reproductive tract, these doses are greater than likely human exposure. Additionally, two other in vivo mechanistic studies have reported potential deleterious effects of BPA on fetal Leydig cell function, independent of any change in the number of the Leydig cells (N'Tumba-Byn et al. 2012, Ben Maamar et al. 2015).

It should be noted that BPA is being replaced with other bisphenol compounds in some manufacturing applications, as a result of consumer concern about BPA toxicity. One example is bisphenol C (BPC), which in one study strongly inhibited testosterone production in an ex vivo assay, but at $100 \mathrm{mg} / \mathrm{kg} /$ day in utero (GD 14-18) only weakly inhibited fetal testis testosterone production and testis gene expression ex vivo on GD 18. Further, in utero BPC exposure at 100 and $200 \mathrm{mg} / \mathrm{kg} /$ day did not significantly affect the reproductive tract of male offspring (Gray et al. 2019). In another result that is contrast to these reports of fetal testis toxicity of BPA, Dere et al. reported a whole-life BPA toxicity experiment in the rat model, which was conducted as part of the Consortium Linking Academic and Regulatory Insights on BPA Toxicity (CLARITY-BPA) study. To address the concerns of the non-monotonic dose-responsive nature of the BPA, the CLARITY-BPA consortium study investigated a wide BPA dose range 
from 2.5 to $25,000 \mu \mathrm{g} / \mathrm{kg} /$ day in rats from GD 6 until parturition, followed by treatment from PND 1 to 90, and the testes and sperm were collected for evaluation. Due to the design, outcomes of this study cannot be attributed solely to fetal exposure, and fetal endpoints were not directly measured. However, this study did not find any significant alterations in the histopathologic, morphometric, and molecular endpoints evaluated in adult rats, suggesting that under the conditions of this consortium study, the rat testis is not sensitive to BPAinduced toxicities (Dere et al. 2018). In summary, the current data from rodent studies provide mixed evidence that gestational BPA exposure can negatively affect male reproductive system development. The relevant BPA exposure level in humans is relatively low (Vandenberg et al. 2007), but there are reports of non-monotonic BPA dose-response for many endpoints (Heindel et al. 2020). Therefore, caution should be taken while extrapolating animal data to human effect.

\section{An antiandrogenic class of drugs analgesic medications}

Unsurprisingly, studies on fetal testicular toxicity of analgesics and NSAIDs predate other categories of fetal testicular toxicants, with papers published as early as 1967, but the compounds investigated in these papers are quite diverse, and the rate of publication on this topic has also increased since 2015. Epidemiological evidence supports an association between in utero exposure to over-the-counter analgesics, including some non-steroidal anti-inflammatory drugs (NSAIDs), and the development of male reproductive disorders. A recent review concluded that there is increasing evidence that analgesics impair testis development and male reproductive function (Hurtado-Gonzalez \& Mitchell 2017). Data from experimental models largely support claims of adverse effects. In one study, gestational exposure to indomethacin, a cyclooxygenase inhibitor and NSAID, led to decreased rat testis weight and testicular prostaglandin $\mathrm{E}_{2}\left(\mathrm{PGE}_{2}\right)$ level but had no effect on intratesticular testosterone or AGD (Dean et al. 2013). Another study by the same group reported that exposure to indomethacin $(0.8 \mathrm{mg} / \mathrm{kg} /$ day $)$ from GD 15.5 to 18.5 or acetaminophen $(350 \mathrm{mg} / \mathrm{kg})$ from GD 13.5 to 21.5 significantly reduced fetal testicular germ cell number and accelerated differentiation of germ cells (Dean et al. 2016). A human fetal testis xenograft experiment found a similar effect of exposure to acetaminophen and ibuprofen on fetal germ cells, including a decrease in fetal germ cell number and altered expression of germ cell differentiation markers (Hurtado-Gonzalez \& Mitchell 2017). Antiandrogenic effects have been reported, as well. A recent study reported that the analgesic dipyrone (metamizole) and its two main metabolites (4-methylaminoantipyrine (MAA) and 4-aminoantipyrine (AA)) inhibit testosterone biosynthesis in vitro at high concentration but not at therapeutically relevant doses in vivo (Passoni et al. 2018). These experimental results are consistent with epidemiological evidence that use of analgesics, including acetaminophen, ibuprofen, and aspirin, during pregnancy is associated with reduced AGD and increased risk of undescended testis (Jensen et al. 2010, Kristensen et al. 2011, Fisher et al. 2016, Kilcoyne \& Mitchell 2019).

The molecular mechanisms of analgesic-induced disruption of fetal testis development are partially understood. Prostaglandins (PGs) are important endogenous mediators in paracrine and autocrine signaling processes, involved in various reproductive functions. Cyclooxygenase 1 (COX1) and COX2 are critical enzymes involved in the synthesis of PGs from arachidonic acid. Because acetaminophen and the NSAIDs exert their effect by inhibiting the PG synthesis pathway and can cross the placenta, altered PG levels in the fetal testis may disturb fetal steroidogenesis, making pregnant women and children vulnerable (Passoni et al. 2018). Although most animal studies show a marginal effect of gestational analgesic exposure on testis development, analgesics are taken intentionally and at higher exposure levels than typical environmental exposures, which means that these effects may pose significant risks during pregnancy. NSAIDs also present a possibly relevant comparison for phthalates, as some papers have hypothesized that disrupted cholesterol metabolism or arachidonic acid signaling contribute to phthalate toxicity (Beverly et al. 2014, Clewell et al. 2020).

\section{PPAR signaling disruption perfluorinated alkyl substances (PFAS)}

Perfluoroalkyl substances (PFAS) are synthetic chemicals widely used as industrial lubricants and surfactants, as well as in products like clothing, household utensils, and food wrapping. Like polychlorinated biphenyls (PCBs), polychlorinated dibenzofurans (PCDFs), polychlorinated dibenzodioxins (PCDDs), and organochlorine pesticides, PFAS are classified as persistent organic pollutants (POPs), toxic environmental chemicals that are generally resistant to environmental degradation, widespread in soil, water and air. Because PFAS are extremely environmentally persistent and widespread in environments around the world, wild animals and humans are ubiquitously exposed to PFAS. PFAS exert general and developmental toxicity. Several publications in 2003 reported that gestational perfluorooctane sulfonate (PFOS) exposure in rodent models resulted in extensive pup mortality, growth restriction, and developmental delays (Lau et al. 2003, Thibodeaux et al. 2003). Similar to phthalates, a possible mechanistic component of PFAS toxicity is binding to PPARs (Szilagyi et al. 2020). 
Conversely, data on the impact of low-dose PFAS exposures on the fetal testis are scarce. Several recent studies have evaluated the effects of in utero PFOS exposure in mouse and rat fetal testis, as well as laterlife effects, focusing mostly on Leydig cell function. Low-dose PFOS, ranging from $0.3-20 \mathrm{mg} / \mathrm{kg}$ in various studies, has led to altered neonatal (PND 1), pubertal (PND 21), young adult (PND 35-63), and adult (PND 90) testis outcomes. Reported effects have included reduced fetal testosterone biosynthesis, perturbations of lipid mediators in neonatal testis, reduced testosterone production, reduced Leydig cell number, and lower epididymal sperm count in young adults. PFOS decreased mRNA and protein expression of Leydig cell and Sertoli cell markers in adult testis, altered the Wnt signaling pathway, down-regulated GSK-3 $\beta$ phosphorylation, and up-regulated phosphorylation of $\beta$-catenin and cyclin D1, which could inhibit steroidogenesis directly and lead to the impairment of Leydig cell mitosis, development, and function (Zhao et al. 2014, Lai et al. 2017, Zhang et al. 2020). One study reported a nonmonotonic effect of PFOS on Leydig cell function at PND 70, with testosterone levels increased by $1 \mathrm{mg} / \mathrm{kg}$ PFOS but decreased testosterone and Leydig cell loss in the 2.5 and $5 \mathrm{mg} / \mathrm{kg}$ groups (Song et al. 2018). In one well-designed ex vivo culture study, PFOA reduced testosterone, progesterone, cAMP, and the expression of the critical steroidogenic gene, Star, in both fetal and adult rat testes (Eggert et al. 2019), suggesting that PFAS may exert antiandrogenic effects through a phthalatelike mechanism in the rat testis. This is consistent with a report in which gestational exposure of mice to $5 \mathrm{mg} / \mathrm{kg} /$ day PFOA led to reduced testosterone in PND 21 male offspring. The authors also reported histopathological indicators of testicular injury; however, without quantification, it was unclear whether the reported effects reflected slight differences in the developmental stage or fixation artifacts (Bao et al. 2021).

As PFOS and perfluorooctanoic acid (PFOA) are phased out of the market, many more PFAS are introduced as substitutes, including hexafluoropropylene oxide dimer acid [(HFPO-DA), GenX]. In one experiment, exposure of pregnant rats to 1 to $500 \mathrm{mg}$ HFPO-DA/kg/ day during male reproductive development (GD14-18) did not result in changes in in vitro receptor activity, testosterone production, or expression of key genes involved in male reproductive development in the fetal testis but reduced male reproductive tissue weights (Conley et al. 2019). Exposure to another PFAS, perfluorononanoic acid (PFNA) during gestation caused alterations in Leydig and Sertoli cell function that were detectable in neonatal testis as decreased expression of SF-1, Leydig cell markers (STAR, CYP17, HSD3B, and HSD17B), and Sertoli cell markers (WT1 and AMH) (Singh \& Singh 2019). Given wide exposure to PFAS and evidence that PFAS threaten male reproductive system development, future studies will be needed to clarify the PFAS mode of action on the male reproductive axis, including more studies of emerging PFAS chemicals, using physiologically relevant exposure routes and concentration levels.

\section{Remaining questions and future perspectives Resolving questions about phthalate toxicity}

Comparison to other fetal testis toxicants provides some relevant insights about phthalate toxicity. The idea that phthalates act through an estrogenic mechanism has been largely, but not completely, abandoned. Phthalate toxicity bears little resemblance to bisphenol toxicity, as described above. However, the rapid metabolism of BPA limits its toxicity in most animal studies. On the other hand, disruption of arachidonic acid signaling by analgesics and activation of PPARs by PFAS result in some effects that are phthalate-like. PFAS cause germ cell death and reduce testosterone through a similar mechanism to the phthalates, by reducing the expression of steroidogenic enzymes. NSAIDs, meanwhile, alter germ cell differentiation and survival, similar to phthalates. Many of the effects of phthalates remain unique, however, including the induction of MNGs in the fetal testis and the testicular dysgenesis phenotype, which limits the utility of comparing phthalate toxicity to any other class of fetal testicular toxicants.

Two of the major knowledge gaps in phthalate toxicity can be illustrated using the adverse outcome pathway (AOP) concept (Fig. 2). First, as mentioned above, hypothesized AOPs to describe phthalates' antiandrogenic mode of action and the consequences of suppressing testosterone production during fetal testis development explicitly denote that there is no consensus molecular initiating event (Howdeshell et al. 2015, Conley et al. 2018, Arzuaga et al. 2019, Clewell et al. 2020, Gray et al. 2020). Methods for addressing this gap could include screening for protein-small molecule interactions, and in particular, revisiting questions about PPAR-driven mechanisms of phthalate toxicity. Phthalates are peroxisome proliferators, and like many other peroxisome proliferators, they are linked to cancers of the liver in rodents (Oshida et al. 2015, Corton et al. 2018). There is evidence that activation of PPAR signaling is not a component of the phthalate toxicity mechanism in the fetal testis (Ward et al. 1998, Hannas et al. 2012). However, the possibility has not been ruled out that phthalates bind to PPARs other than PPARA or cause effects downstream of PPARs other than direct activation of gene expression, such as antagonism of other PPAR-ligands interactions, non-canonical signaling, or inflammatory actions (Varga et al. 2011). In fact, many phthalates are predicted in silico to bind to all three human PPAR isoforms. Further, interactions between PPARs and other nuclear receptors, such as RARs, could explain a portion of the phthalate toxicity mechanism (Dufour et al. 2003, Spade et al. 2019b). 


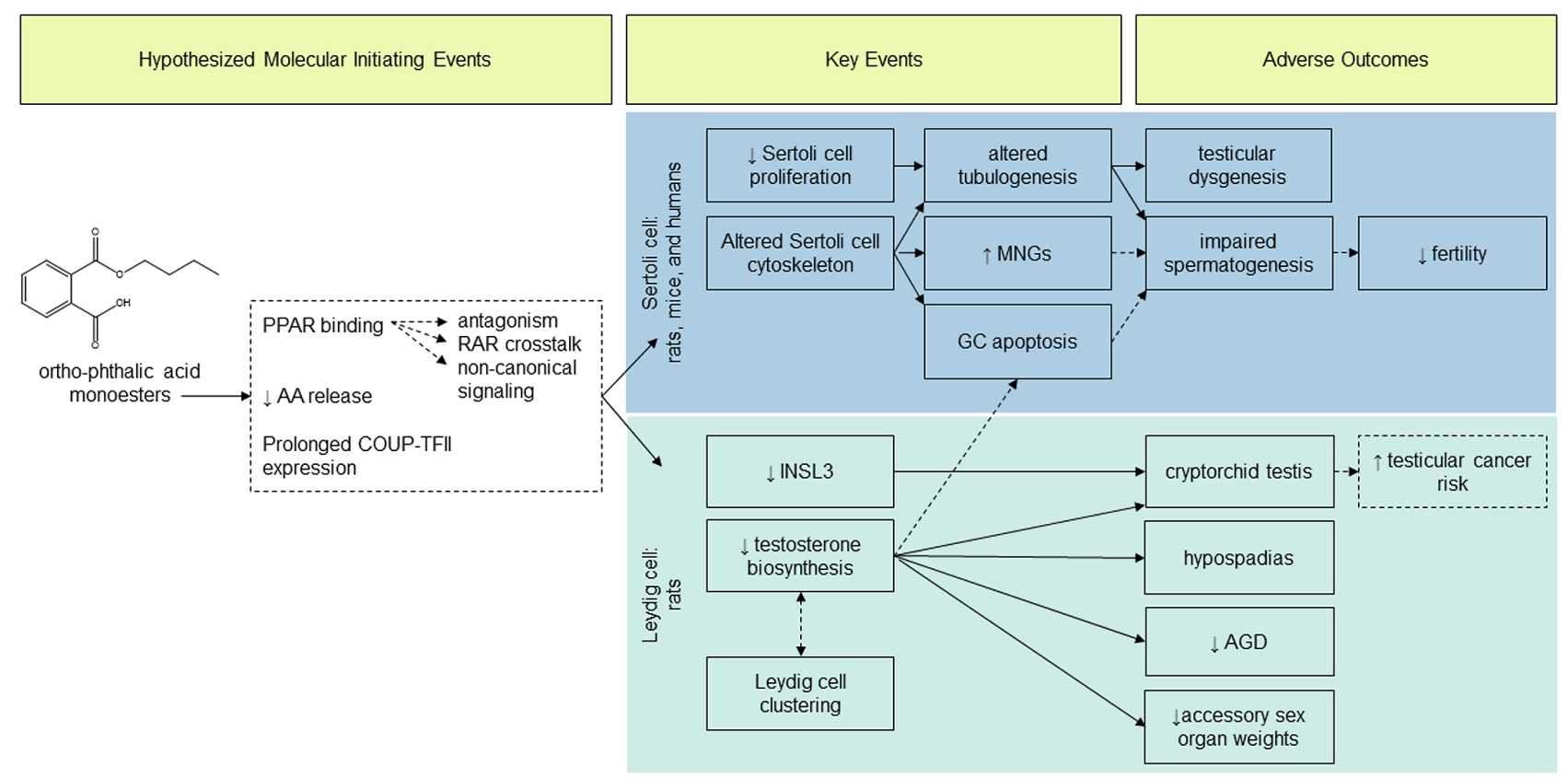

Figure 2 Hypothesized adverse outcome pathway (AOP) for phthalate toxicity in the fetal testis. Based solely on experimental evidence, there are a number of gaps in the present understanding of phthalate toxicity. Hypothetical steps in the AOP and hypothesized relationships between key events are represented with dashed lines. The biggest knowledge gap is the lack of a confirmed molecular initiating event(s). It is clear that ortho-phthalates are metabolized to monoesters, which cause toxicity in the fetal testis. Proposed molecular initiating events are numerous but have included PPAR binding, decreased arachidonic acid (AA) release, and prolonged expression of the nuclear receptor COUP-TFII in Leydig cells. There is no evidence that phthalates inhibit the androgen receptor or directly activate the PPARA-mediated gene expression. The relationship between Leydig-reduced synthesis of Leydig cell-derived hormones, INSL3 and testosterone, and adverse outcomes, such as cryptorchid testis, is very clear. Cryptorchid testis is associated with testicular cancer epidemiologically, but there is no accepted rodent model of germ cell cancer in which to demonstrate this link experimentally. Sertoli cell effects of phthalates are less frequently studied, but the relationship between altered Sertoli cell proliferation and cytoskeletal processes with changes in cord morphogenesis (tubulogenesis) and adverse germ cell outcomes is well supported. Animals treated with phthalates during gestation have reduced spermatogenesis in later life. This could be caused by functional deficits in Sertoli cells or simply by reduced Sertoli cell number, but there is reason to hypothesize that these changes contribute to reduced fertility. Finally, it is likely that there are connections between the Leydig- and Sertoli cell-mediated effects of phthalates. For example, androgen insufficiency could contribute to germ cell loss. The long-term impact of multinucleated germ cells and germ cell apoptosis is unclear, given the high rate of germ cell loss in normal testes in the early postnatal development window.

Beyond activation or inhibition of PPARs or crosstalk between PPARs and other nuclear receptors, at least two additional MIEs have been proposed in phthalate AOPs, both primarily related to testosterone. First, there is experimental evidence that phthalates prolong the expression of the nuclear receptor COUP-TFII in rat, but not in mouse, Leydig cells, leading to suppression of Leydig cell SF-1-regulated gene expression and reduced production of testosterone (van den Driesche et al. $2012 b$ ). This could explain the mechanism of phthalates' antiandrogenic effects, as well as the species differences. Secondly, it has been hypothesized that phthalates disrupt Leydig cell arachidonic acid release by inhibiting the enzyme CPLA2, leading to decreased expression of steroidogenesis-associated genes (Clewell et al. 2020).

The second gap is the incomplete understanding of the mechanisms that underlie the species differences between rats, mice, and humans. There is a paucity of mouse data, relative to the vast number of phthalate studies that have been conducted in the rat model. Further comparisons between mice and rats could help to resolve this knowledge gap. Notably, far fewer experiments have addressed the effects of phthalates on Sertoli cells than Leydig cells or even germ cells (Table 1). This is likely due in part to the relative difficulty of directly measuring features like Sertoli cell number, differentiation, cytoskeletal structure, or germ cell-Sertoli cell contacts, compared to more readily quantified outcomes like testosterone or even MNGs. MNGs are the one feature that has been clearly identified in the fetal testes of all tested species following phthalate exposure. Additionally, no class of toxicants other than phthalates has been reported to induce MNGs in the fetal testis, which means that identifying the molecular mechanisms of MNG induction could provide key clues for understanding phthalate toxicity. Notably, we have demonstrated that in the rat fetal testis, medium chainlength phthalates that are antiandrogenic also disrupt seminiferous cord development and cause induction of MNGs (Spade et al. 2018). Given the consistency of MNG induction, this effect or other measures of impaired seminiferous cord development, such as cord diameter, 
may be the most human-like metrics for phthalate doseresponse analysis. Further dose-response assessment of phthalate-induced histopathology will help to determine whether the fetal rat testis has a similar sensitivity to the antiandrogenic and cord-related effects of phthalates. However, whether a single MIE or two MIEs explain the effects of phthalates on Leydig cells and Sertoli cells, respectively, there is a qualitative difference between the Leydig cell response to phthalates in rats, relative to humans and mice. Additional studies of phthalate toxicity in the mouse model may help to resolve the cause of this difference.

\section{Later-life effects of fetal testicular toxicant exposures}

There is extensive evidence that environmental exposures and pharmaceuticals can alter multiple processes that are required for normal fetal testis development. This is most relevant to human health if these changes result in diminished fertility or increased risk of other adverse reproductive health outcomes in later life. Because latent effects are more difficult to demonstrate definitively, some questions about later-life effects of fetal testis toxicity remain. Some of the most straightforward evidence for later-life adverse outcomes of fetal testis toxicity is associated with antiandrogen exposure. Antiandrogens inhibit masculinization of the male reproductive tract, causing congenital defects, such as undescended testis and hypospadias (Hotchkiss et al. 2004, Noriega et al. 2005, Conley et al. 2018, Gray et al. 2020). These effects are caused by gestational phthalate exposure in the rat (Fisher et al. 2003, Wilson et al. 2004, Foster 2006), and despite the lack of clear experimental evidence that phthalates are antiandrogenic in the human fetal testis, some epidemiological studies have found a link between gestational phthalate exposure and hypospadias in humans. The strength of this link is debated (Lottrup et al. 2006, Jensen et al. 2015), and other studies have concluded that there was no significant association between phthalate exposure and cryptorchidism or hypospadias in human cohorts (Anand-Ivell et al. 2018). Hypospadias and cryptorchid testis are common human male reproductive defects that require surgical correction. Moreover, it is presumed that any environmental exposure causing an increased risk of cryptorchidism has later-life effects, given the relationship between undescended testes and reduced fertility and seminoma risk (Yavetz et al. 1992, Pettersson et al. 2007).

The impact of phthalates on testicular structure, as observed by histopathology (i.e. 'testicular dysgenesis'), is persistent. Phthalate-induced testicular histologic lesions, germ cell loss, and tubular atrophy persist throughout adulthood in the rat (Barlow \& Foster 2003, Barlow et al. 2004, Mahood et al. 2007, Gray et al. 2009, Repouskou et al. 2019). Phthalate-induced longterm decreases in Sertoli cell number may mediate a decrease in fertility (Dostal et al. 1988). Rats treated with phthalates in utero also exhibit decreased sperm count and quality later in life, leading to early reproductive aging and senescence (Barakat et al. 2017, Axelstad et al. 2018, Dostalova et al. 2020). MNGs are a unique toxicologic marker of fetal testicular phthalate exposure. It was previously suggested that MNGs or developmentally delayed fetal germ cells were potential carcinoma in situ (CIS) cell precursors (Ferrara et al. 2006, Sonne et al. 2008). However, MNGs are degenerative and do not persist postnatally in WT mice (Saffarini et al. 2012). While these germ cell changes may not directly diminish later-life testis function, they are relevant markers of phthalate-driven Sertoli cell toxicity, which can persist into adulthood. In addition to effects that are mediated by structural changes caused by altered Sertoli cell development, fetal phthalate exposure disrupts later-life development of adult Leydig cells (Kilcoyne et al. 2014, Chen et al. 2017). Similarly, other fetal testis toxicants, many of which have not been studied as thoroughly as phthalates, are likely to cause later-life effects on testis function. Several publications address the later-life effects of DES and BPA and adult Leydig cell development and fertility (Fielden et al. 2002, Ivell et al. 2013). There is also a rich literature on the transgenerational effects of some in utero exposures on male reproductive biology (Anway et al. 2005, Manikkam et al. 2012, 2013, Stenz et al. 2019, Barakat et al. 2020), which implies a persistent effect of in utero exposures on the development and function of the testis, resulting in altered spermatozoa.

\section{Mixtures}

To this point, we have only reviewed studies performed on a single-chemical basis, as is the standard of practice for chemical risk assessment and most toxicology studies. Moreover, we have focused heavily on phthalates, for which tolerable exposure levels below which toxicity is not observed in vivo are relatively high. Low doses of phthalates found to have antiandrogenic or seminiferous cord effects in animal studies are often in the range of $10-100 \mathrm{mg} / \mathrm{kg} /$ day for a single phthalate (Boekelheide et al. 2009, Heger et al. 2012, Ungewitter et al. 2017). Although phthalates are ubiquitous in built environments and many consumer products, normal human exposure levels to single phthalates are much lower than $100 \mathrm{mg} / \mathrm{kg} /$ day. Most humans are not exposed to phthalate doses that exceed the EPA reference dose of $20 \mu \mathrm{g} / \mathrm{kg} /$ day, although exposures can exceed the reference dose in sensitive populations. Exposure levels are highest in medical settings, especially in premature neonates, who undergo treatments such as total parenteral nutrition that can raise the risk of exposure to phthalates used in medical plastics (Kavlock et al. 2006). Exposure estimates in neonates in some neonatal intensive care settings have ranged from 
5 to $22.6 \mathrm{mg} / \mathrm{kg} /$ day (Loff et al. 2000, Calafat et al. 2004, Kavlock et al. 2006, Koch et al. 2006).

Additionally, humans, including pregnant women, are exposed to multiple chemicals simultaneously. Drugdrug and drug-environmental chemical interactions during pregnancy might impose a serious risk on both mothers and children. According to the FDA, 50\% of pregnant women self-report taking at least one medicine during pregnancy. In addition to analgesics, which we have reviewed, these include drug therapies for the management of the pregnancy complications, such as diabetes, morning sickness, or high blood pressure. As drugs are taken deliberately and usually at a relatively high dose compared to involuntary exposure to environmental chemicals, the assessment of their potential adverse impact on both mothers and their children is critical. For example, betamethasone, a glucocorticoid, is used in women at risk of preterm delivery. Recent studies found that in utero betamethasone exposure can disrupt fetal male reproductive development (Borges et al. 2016, Pedrana et al. 2016, de Barros et al. 2018). Similar investigations have been published recently on caffeine, the anti-diabetic drug, metformin, the antiviral drugs, acyclovir and ganciclovir, the anti-epileptic drug, carbamazepine, the antiandrogen and hair loss drug, finasteride, the cholesterol-reducing drug, simvastatin, and others (Bowman et al. 2003, Tartarin et al. 2012, Andretta et al. 2014, Nihi et al. 2014, Ogunwole et al. 2015, Veroniki et al. 2017, Meyer et al. 2018, Beverly et al. 2019). Collectively, research regarding the potential risk of medications used in pregnancy on the developing male reproductive system remains inadequate, particularly given the higher exposure levels for drugs relative to environmental chemicals, as indicated in the review by Kilcoyne and Mitchell (2019). Therefore, additional studies on many therapeutic drugs used during pregnancy are needed.

In light of this challenge, studies of toxicant mixtures using in utero rodent exposure models have been reported with increasing frequency, as described in a recent review (Howdeshell et al. 2017). Many of these studies have been designed to test the hypothesis that mixture response for antiandrogenic chemicals with similar modes of action is predicted better by doseaddition models than response-addition models or, in other words, that exposure at sub-toxic doses to two or more compounds that act on the same targets can produce a toxic result. In an early example of this effort, rats exposed to vinclozolin and procymidone, which are dicarboximide fungicides and androgen receptor antagonists, showed significantly higher rates of hypospadias and vaginal pouch than either compound alone (Gray et al. 2001). More recently, large studies of chemical combinations with similar mechanisms of action have been reported, with a focus on phthalates. In these experiments, dose-addition modeling has accurately predicted the reduction of fetal testosterone production and androgen-sensitive postnatal male reproductive tract development in up to five phthalate mixture studies (Howdeshell et al. 2008, 2015). Dose-addition modeling also predicts outcomes for mixtures with multiple mechanisms that target the same pathway. For example, co-exposure to DBP, a fetal testosterone production inhibitor, and procymidone, an androgen receptor antagonist, at doses that were individually sub-toxic, caused an increased incidence of hypospadias and vaginal pouch (Hotchkiss et al. 2010). Recent studies have addressed much more complex antiandrogenic combinations: androgen receptor antagonists (procymidone, vinclozolin, and pyrifluquinazon), phthalates as testosterone synthesis inhibitors (BBP, DBP, DEHP, DiBP, DiHeP and DPeP), pesticides with dual mechanisms of androgen receptor antagonism and testosterone synthesis inhibition (prochloraz and linuron), and a cholesterol synthesis inhibitor (simvastatin) (Rider et al. 2010, Conley et al. 2018), with similar findings. These results have been supported by a study comparing antiandrogenic effects of endocrine-disrupting pharmaceuticals and environmental chemicals in cultured human fetal testis tissue (Gaudriault et al. 2017). On the other hand, dose addition is not the best model to predict mixture toxicity for chemicals working on different pathways but affecting the same target tissue. With DBP (androgen pathway) and 2,3,7,8-tetrachlorodibenzodioxin (TCDD, AHR pathway), response addition more accurately models some of the adverse endpoints in the co-exposure group (Rider et al. 2010). To serve the goal of accurately assessing the hazard posed by environmental chemicals and pharmaceuticals, many more mixture studies may need to be performed, including mixtures of compounds from different classes and with dissimilar modes of action, at environmentally relevant dose levels. Mixture studies involving phthalates and classes of compounds that may share some aspects of their toxicity mechanisms, such as analgesics or PFAS, could also help to clarify the knowledge gaps in the phthalate AOP.

\section{Emerging technologies and mechanisms}

Several future directions are likely to grow from the last decade of fetal testis toxicity research, aided by advances in research technologies. The advent of single-cell RNAsequencing (scRNA-seq) has enhanced understanding of testis biology. The testis is an ideal organ to apply such technology, because of its many and varied cellular differentiation states. However, to date, only two experiments have used this technology to describe fetal testis development (Stevant et al. 2018, Law et al. 2019). These experiments have confirmed existing knowledge but have also added knowledge, for example, about the timing of specification of supporting cell and steroidogenic cell precursors from SF-1-positive progenitors. This technology will be an important tool for toxicologists seeking to 
answer questions about the influence of compounds such as phthalates on cell type specification and differentiation, which are easily lost in the average values produced by bulk gene expression analysis.

The last decade has also produced advances in the understanding of fetal testis development and maintenance of the differentiated testis phenotype. Recent work has further clarified the interplay between 'testis' and 'ovary' signaling processes in fetal supporting cells (Nicol \& Yao 2015, Nicol et al. 2018), as well as the under-appreciated role of resident macrophages in testicular development (DeFalco et al. 2014). We have been interested in the interaction between phthalates and retinoic acid, which can disrupt these cell type specification processes (Spade et al. 2019a,b). Several studies have also begun to address the question of phthalate impacts on testicular macrophage function, following both fetal exposure and prepubertal exposure (Murphy et al. 2014, Walker et al. 2020). It is likely that the keys to understanding phthalate toxicity mechanisms more fully lie in cellular developmental processes that have not as yet been the focus of toxicology studies.

\section{Conclusion}

The fetal testis is a remarkable organ. Testis development happens in a short time span beginning later than most organs, relies on multiple signaling processes, and involves migration and differentiation of multiple cell types, ultimately giving rise to structures that support spermatogenesis and the endocrine functions that program the masculinization of the male fetus. This process is highly susceptible to disruption by environmental toxicants. Phthalates are a key class of fetal testis toxicants, and although they have been studied intensely over the past 20 years, the molecular initiating events in phthalate toxicity remain to be identified. Filling these knowledge gaps will be a significant challenge, but it is likely to contribute to the knowledge of basic testis biology and a better understanding of how in utero toxicant exposures impact long-term and even transgenerational health outcomes.

\section{Supplementary materials}

This is linked to the online version of the paper at https://doi. org/10.1530/REP-20-0592.

\section{Declaration of interest}

The authors declare that there is no conflict of interest that could be perceived as prejudicing the impartiality of this review.

\section{Funding}

This work was funded by the National Institute of Environmental Health Sciences [R00 ES025231].

\section{Author contribution statement}

$\mathrm{HL}$ and D S contributed equally to the concept, research, and writing of this manuscript. D S designed the figures.

\section{Acknowledgement}

The authors thank Vinald Francis for scientific illustrations.

\section{References}

Albert O \& Jegou B 2014 A critical assessment of the endocrine susceptibility of the human testis to phthalates from fetal life to adulthood. Human Reproduction Update 20 231-249. (https://doi.org/10.1093/humupd/ dmt050)

Albro PW 1986 Absorption, metabolism, and excretion of di(2-ethylhexyl) phthalate by rats and mice. Environmental Health Perspectives $\mathbf{6 5}$ 293-298. (https://doi.org/10.1289/ehp.8665293)

Allard EK \& Boekelheide K 1996 Fate of germ cells in 2,5-hexanedioneinduced testicular injury II: atrophy persists due to a reduced stem cell mass and ongoing apoptosis. Toxicology and Applied Pharmacology 137 149-156. (https://doi.org/10.1006/taap.1996.0067)

Anand-Ivell R, Cohen A, Norgaard-Pedersen B, Jonsson BAG, Bonde JP, Hougaard DM, Lindh CH, Toft G, Lindhard MS \& Ivell R 2018 Amniotic fluid INSL3 measured during the critical time window in human pregnancy relates to cryptorchidism, hypospadias, and phthalate load: a large case-control study. Frontiers in Physiology 9 406. (https://doi. org/10.3389/fphys.2018.00406)

Andersson AM, Bay K, Frederiksen H \& Skakkebaek NE 2016 Endocrine disrupters: we need research, biomonitoring and action. Andrology 4 556-560. (https://doi.org/10.1111/andr.12244)

Andretta RR, Okada FK, Paccola CC, Stumpp T, De Oliva SU \& Miraglia SM 2014 Carbamazepine-exposure during gestation and lactation affects pubertal onset and spermatic parameters in male pubertal offspring. Reproductive Toxicology 44 52-62. (https://doi.org/10.1016/j. reprotox.2013.09.009)

Ankley GT, Bennett RS, Erickson RJ, Hoff DJ, Hornung MW, Johnson RD, Mount DR, Nichols JW, Russom CL, Schmieder PK et al. 2010 Adverse outcome pathways: a conceptual framework to support ecotoxicology research and risk assessment. Environmental Toxicology and Chemistry 29 730-741. (https://doi.org/10.1002/etc.34)

Anway MD, Cupp AS, Uzumcu M \& Skinner MK 2005 Epigenetic transgenerational actions of endocrine disruptors and male fertility. Science 308 1466-1469. (https://doi.org/10.1126/science.1108190)

Arzuaga X, Walker T, Yost EE, Radke EG \& Hotchkiss AK 2019 Use of the adverse outcome pathway (AOP) framework to evaluate species concordance and human relevance of dibutyl phthalate (DBP)-induced male reproductive toxicity. Reproductive Toxicology 96 445-458. (https://doi.org/10.1016/j.reprotox.2019.06.009)

Axelstad M, Hass U, Scholze M, Christiansen S, Kortenkamp A \& Boberg J 2018 EDC Impact: reduced sperm counts in rats exposed to human relevant mixtures of endocrine disrupters. Endocrine Connections 7 139-148. (https://doi.org/10.1530/EC-17-0307)

Balakrishnan B, Henare K, Thorstensen EB, Ponnampalam AP \& Mitchell MD 2010 Transfer of bisphenol A across the human placenta. American Journal of Obstetrics and Gynecology 202 393.e1-393.e7. (https://doi.org/10.1016/j.ajog.2010.01.025)

Bao J, Zhang Y, Zhang L \& Wang X 2021 Effects of maternal exposure to PFOA on testes of male offspring mice. Chemosphere 272129585. (https://doi.org/10.1016/j.chemosphere.2021.129585)

Barakat R, Lin P-CP, Rattan S, Brehm E, Canisso IF, Abosalum ME, Flaws JA, Hess R \& Ko C 2017 Prenatal exposure to DEHP induces premature reproductive senescence in male mice. Toxicological Sciences $\mathbf{1 5 6}$ 96-108. (https://doi.org/10.1093/toxsci/kfw248)

Barakat R, Lin PC, Park CJ, Zeineldin M, Zhou S, Rattan S, Brehm E, Flaws JA \& Ko CJ 2020 Germline-dependent transmission of male reproductive traits induced by an endocrine disruptor, di-2-ethylhexyl phthalate, in future generations. Scientific Reports 10 5705. (https://doi. org/10.1038/s41598-020-62584-w) 
Barlow NJ \& Foster PM 2003 Pathogenesis of male reproductive tract lesions from gestation through adulthood following in utero exposure to Di(n-butyl) phthalate. Toxicologic Pathology 31 397-410. (https://doi. org/10.1080/01926230390202335)

Barlow NJ, Phillips SL, Wallace DG, Sar M, Gaido KW \& Foster PM 2003 Quantitative changes in gene expression in fetal rat testes following exposure to di(n-butyl) phthalate. Toxicological Sciences 73 431-441. (https://doi.org/10.1093/toxsci/kfg087)

Barlow NJ, Mcintyre BS \& Foster PM 2004 Male reproductive tract lesions at 6,12 , and 18 months of age following in utero exposure to di(n-butyl) phthalate. Toxicologic Pathology 32 79-90. (https://doi. org/10.1080/01926230490265894)

Behringer RR 1995 The Müllerian inhibitor and mammalian sexual development. Philosophical Transactions of the Royal Society of London: Series B, Biological Sciences 350 285-288. (https://doi.org/10.1098/ rstb.1995.0163)

Ben Maamar M, Lesne L, Desdoits-Lethimonier C, Coiffec I, Lassurguere J, Lavoue V, Deceuninck Y, Antignac JP, Le Bizec B, Perdu E et al. 2015 An investigation of the endocrine-disruptive effects of bisphenol $\mathrm{A}$ in human and rat fetal testes. PLOS ONE 10 e0117226. (https://doi.org/10.1371/ journal.pone.0117226)

Beverly BE, Lambright CS, Furr JR, Sampson H, Wilson VS, Mcintyre BS, Foster PM, Travlos G \& Gray LE 2014 Simvastatin and dipentyl phthalate lower ex vivo testicular testosterone production and exhibit additive effects on testicular testosterone and gene expression via distinct mechanistic pathways in the fetal rat. Toxicological Sciences $\mathbf{1 4 1}$ 524-537. (https://doi.org/10.1093/toxsci/kfu149)

Beverly BEJ, Furr JR, Lambright CS, Wilson VS, Mcintyre BS, Foster PMD, Travlos G \& Earl Gray L 2019 In utero exposure to simvastatin reduces postnatal survival and permanently alters reproductive tract development in the Crl:CD(SD) male rat. Toxicology and Applied Pharmacology 365 112-123. (https://doi.org/10.1016/j.taap.2019.01.001)

Boekelheide K 1988 Rat testis during 2,5-hexanedione intoxication and recovery II: dynamics of pyrrole reactivity, tubulin content, and microtubule assembly. Toxicology and Applied Pharmacology 92 28-33. (https://doi.org/10.1016/0041-008x(88)90224-4)

Boekelheide K 2005 Mechanisms of toxic damage to spermatogenesis. Journal of the National Cancer Institute: Monographs 34 6-8. (https:// doi.org/10.1093/jncimonographs/lgi006)

Boekelheide K, Kleymenova E, Liu K, Swanson C \& Gaido KW 2009 Dose-dependent effects on cell proliferation, seminiferous tubules, and male germ cells in the fetal rat testis following exposure to di(n-butyl) phthalate. Microscopy Research and Technique 72 629-638. (https:// doi.org/10.1002/jemt.20684)

Borch J, Metzdorff SB, Vinggaard AM, Brokken L \& Dalgaard M 2006 Mechanisms underlying the anti-androgenic effects of diethylhexyl phthalate in fetal rat testis. Toxicology 223 144-155. (https://doi. org/10.1016/j.tox.2006.03.015)

Borges CS, Dias AF, Rosa JL, Silva PV, Silva RF, Barros AL, Sanabria M, Guerra MT, Gregory M, Cyr DG et al. 2016 Alterations in male rats following in utero exposure to betamethasone suggests changes in reproductive programming. Reproductive Toxicology 63 125-134. (https://doi.org/10.1016/j.reprotox.2016.05.021)

Bornehag CG, Carlstedt F, Jonsson BA, Lindh CH, Jensen TK, Bodin A, Jonsson C, Janson S \& Swan SH 2015 Prenatal phthalate exposures and anogenital distance in Swedish boys. Environmental Health Perspectives 123 101-107. (https://doi.org/10.1289/ehp.1408163)

Bowman CJ, Barlow NJ, Turner KJ, Wallace DG \& Foster PM 2003 Effects of in utero exposure to finasteride on androgen-dependent reproductive development in the male rat. Toxicological Sciences 74 393-406. (https:// doi.org/10.1093/toxsci/kfg128)

Brennan J \& Capel B 2004 One tissue, two fates: molecular genetic events that underlie testis versus ovary development. Nature Reviews: Genetics 5 509-521. (https://doi.org/10.1038/nrg1381)

Calafat AM, Needham LL, Silva MJ \& Lambert G 2004 Exposure to di(2-ethylhexyl) phthalate among premature neonates in a neonatal intensive care unit. Pediatrics 113 e429-e434. (https://doi.org/10.1542/ peds.113.5.e429)

Chen X, Li L, Li H, Guan H, Dong Y, Li X, Wang Q, Lian Q, Hu G \& Ge RS 2017 Prenatal exposure to di-n-butyl phthalate disrupts the development of adult Leydig cells in male rats during puberty. Toxicology 386 19-27. (https://doi.org/10.1016/j.tox.2017.05.004)
Clewell RA, Leonard JA, Nicolas CI, Campbell JL, Yoon M, Efremenko AY, Mcmullen PD, Andersen ME, Clewell HJ, Phillips KA et al. 2020 Application of a combined aggregate exposure pathway and adverse outcome pathway (AEP-AOP) approach to inform a cumulative risk assessment: a case study with phthalates. Toxicology In Vitro 66104855. (https://doi.org/10.1016/j.tiv.2020.104855)

Conley JM, Lambright CS, Evans N, Cardon M, Furr J, Wilson VS \& Gray LE 2018 Mixed 'antiandrogenic' chemicals at low individual doses produce reproductive tract malformations in the male rat. Toxicological Sciences 164 166-178. (https://doi.org/10.1093/toxsci/kfy069)

Conley JM, Lambright CS, Evans N, Strynar MJ, Mccord J, Mcintyre BS, Travlos GS, Cardon MC, Medlock-Kakaley E, Hartig PC et al. 2019 Adverse maternal, fetal, and postnatal effects of hexafluoropropylene oxide dimer acid (GenX) from oral gestational exposure in SpragueDawley rats. Environmental Health Perspectives 127 37008. (https://doi. org/10.1289/EHP4372)

Corton JC \& Lapinskas PJ 2005 Peroxisome proliferator-activated receptors: mediators of phthalate ester-induced effects in the male reproductive tract? Toxicological Sciences 83 4-17. (https://doi.org/10.1093/toxsci/kfi011)

Corton JC, Peters JM \& Klaunig JE 2018 The PPARalpha-dependent rodent liver tumor response is not relevant to humans: addressing misconceptions. Archives of Toxicology 92 83-119. (https://doi. org/10.1007/s00204-017-2094-7)

Coveney D, Cool J, Oliver T \& Capel B 2008 Four-dimensional analysis of vascularization during primary development of an organ, the gonad. PNAS 105 7212-7217. (https://doi.org/10.1073/pnas.0707674105)

Culty M 2009 Gonocytes, the forgotten cells of the germ cell lineage. Birth Defects Research: Part C, Embryo Today: Reviews 87 1-26. (https://doi. org/10.1002/bdrc.20142)

Culty M 2013 Gonocytes, from the fifties to the present: is there a reason to change the name? Biology of Reproduction 89 46. (https://doi. org/10.1095/biolreprod.113.110544)

de Barros JWF, Borges CDS, Missassi G, Pacheco TL \& De Grava Kempinas W 2018 Impact of intrauterine exposure to betamethasone on the testes and epididymides of prepubertal rats. Chemico-Biological Interactions 291 202-211. (https://doi.org/10.1016/j.cbi.2018.06.030)

Dean A, Mungall W, McKinnell C \& Sharpe RM 2013 Prostaglandins, masculinization and its disorders: effects of fetal exposure of the rat to the cyclooxygenase inhibitor-indomethacin. PLOS ONE 8 e62556. (https://doi.org/10.1371/journal.pone.0062556)

Dean A, Van Den Driesche S, Wang Y, McKinnell C, Macpherson S, Eddie SL, Kinnell H, Hurtado-Gonzalez P, Chambers TJ, Stevenson K et al. 2016 Analgesic exposure in pregnant rats affects fetal germ cell development with inter-generational reproductive consequences. Scientific Reports 6 19789. (https://doi.org/10.1038/srep19789)

DeFalco T, Bhattacharya I, Williams AV, Sams DM \& Capel B 2014 Yolk-sac-derived macrophages regulate fetal testis vascularization and morphogenesis. PNAS 111 E2384-E2393. (https://doi.org/10.1073/ pnas.1400057111)

Delfosse V, Grimaldi M, Pons JL, Boulahtouf A, Le Maire A, Cavailles V, Labesse G, Bourguet W \& Balaguer P 2012 Structural and mechanistic insights into bisphenols action provide guidelines for risk assessment and discovery of bisphenol A substitutes. PNAS 109 14930-14935. (https://doi.org/10.1073/pnas.1203574109)

Dere E, Anderson LM, Huse SM, Spade DJ, Mcdonnell-Clark E, Madnick SJ, Hall SJ, Camacho L, Lewis SM, Vanlandingham MM et al. 2018 Effects of continuous bisphenol A exposure from early gestation on 90day old rat testes function and sperm molecular profiles: a CLARITYBPA consortium study. Toxicology and Applied Pharmacology 347 1-9. (https://doi.org/10.1016/j.taap.2018.03.021)

Doerge DR, Twaddle NC, Vanlandingham M \& Fisher JW 2010 Pharmacokinetics of bisphenol A in neonatal and adult Sprague-Dawley rats. Toxicology and Applied Pharmacology 247 158-165. (https://doi. org/10.1016/j.taap.2010.06.008)

Dorman DC, Chiu W, Hales BF, Hauser R, Johnson KJ, Mantus E, Martel S, Robinson KA, Rooney AA, Rudel R et al. 2018 Systematic reviews and meta-analyses of human and animal evidence of prenatal diethylhexyl phthalate exposure and changes in male anogenital distance. Journal of Toxicology and Environmental Health: Part B, Critical Reviews 21 207-226. (https://doi.org/10.1080/10937404.2018.1505354)

Dostal LA, Chapin RE, Stefanski SA, Harris MW \& Schwetz BA 1988 Testicular toxicity and reduced Sertoli cell numbers in neonatal rats 
by di(2-ethylhexyl)phthalate and the recovery of fertility as adults. Toxicology and Applied Pharmacology 95 104-121. (https://doi. org/10.1016/s0041-008x(88)80012-7)

Dostalova P, Zatecka E, Ded L, Elzeinova F, Valaskova E, Kubatova A, Korenkova V, Langerova L, Komrskova K \& Peknicova J 2020 Gestational and pubertal exposure to low dose of di-(2-ethylhexyl) phthalate impairs sperm quality in adult mice. Reproductive Toxicology 96 175-184 (https://doi.org/10.1016/j.reprotox.2020.06.014)

Drake AJ, Van Den Driesche S, Scott HM, Hutchison GR, SeckI JR \& Sharpe RM 2009 Glucocorticoids amplify dibutyl phthalate-induced disruption of testosterone production and male reproductive development. Endocrinology 150 5055-5064. (https://doi.org/10.1210/en.2009-0700)

Dufour JM, Vo MN, Bhattacharya N, Okita J, Okita R \& Kim KH 2003 Peroxisome proliferators disrupt retinoic acid receptor alpha signaling in the testis. Biology of Reproduction 68 1215-1224. (https://doi. org/10.1095/biolreprod.102.010488)

Eggert A, Cisneros-Montalvo S, Anandan S, Musilli S, Stukenborg JB, Adamsson A, Nurmio M \& Toppari J 2019 The effects of perfluorooctanoic acid (PFOA) on fetal and adult rat testis. Reproductive Toxicology 90 68-76. (https://doi.org/10.1016/j.reprotox.2019.08.005)

el Ouali H, Leheup BP, Gelly JL \& Grignon G 1991 Laminin ultrastructural immunolocalization in rat testis during ontogenesis. Histochemistry 95 241-246. (https://doi.org/10.1007/BF00744995)

Emmen JM, Mcluskey A, Adham IM, Engel W, Grootegoed JA \& Brinkmann AO 2000 Hormonal control of gubernaculum development during testis descent: gubernaculum outgrowth in vitro requires both insulin-like factor and androgen. Endocrinology $141 \quad 4720-4727$. (https://doi.org/10.1210/endo.141.12.7830)

Ferrara D, Hallmark N, Scott H, Brown R, McKinnell C, Mahood IK \& Sharpe RM 2006 Acute and long-term effects of in utero exposure of rats to di(n-butyl) phthalate on testicular germ cell development and proliferation. Endocrinology 147 5352-5362. (https://doi.org/10.1210/ en.2006-0527)

Fielden MR, Halgren RG, Fong CJ, Staub C, Johnson L, Chou K \& Zacharewski TR 2002 Gestational and lactational exposure of male mice to diethylstilbestrol causes long-term effects on the testis, sperm fertilizing ability in vitro, and testicular gene expression. Endocrinology 143 3044-3059. (https://doi.org/10.1210/endo.143.8.8968)

Fisher JS, Macpherson S, Marchetti N \& Sharpe RM 2003 Human 'testicular dysgenesis syndrome': a possible model using in-utero exposure of the rat to dibutyl phthalate. Human Reproduction 18 1383-1394. (https:// doi.org/10.1093/humrep/deg273)

Fisher BG, Thankamony A, Hughes IA, Ong KK, Dunger DB \& Acerini CL 2016 Prenatal paracetamol exposure is associated with shorter anogenital distance in male infants. Human Reproduction 31 2642-2650. (https:// doi.org/10.1093/humrep/dew196)

Foster PM 2006 Disruption of reproductive development in male rat offspring following in utero exposure to phthalate esters. International Journal of Andrology 29 140-147, 181-185. (https://doi.org/10.1111/ j.1365-2605.2005.00563.x)

Furr JR, Lambright CS, Wilson VS, Foster PM \& Gray LE 2014 A shortterm in vivo screen using fetal testosterone production, a key event in the phthalate adverse outcome pathway, to predict disruption of sexual differentiation. Toxicological Sciences 140 403-424. (https://doi org/10.1093/toxsci/kfu081)

Gaido KW, Hensley JB, Liu D, Wallace DG, Borghoff S, Johnson KJ, Hall SJ \& Boekelheide K 2007 Fetal mouse phthalate exposure shows that gonocyte multinucleation is not associated with decreased testicular testosterone. Toxicological Sciences 97 491-503. (https://doi. org/10.1093/toxsci/kfm049)

Gaudriault P, Mazaud-Guittot S, Lavoue V, Coiffec I, Lesne L, DejucqRainsford N, Scholze M, Kortenkamp A \& Jegou B 2017 Endocrine disruption in human fetal testis explants by individual and combined exposures to selected pharmaceuticals, pesticides, and environmental pollutants. Environmental Health Perspectives 125 087004. (https://doi. org/10.1289/EHP1014)

Gazouli M, Yao ZX, Boujrad N, Corton JC, Culty M \& Papadopoulos V 2002 Effect of peroxisome proliferators on Leydig cell peripheraltype benzodiazepine receptor gene expression, hormone-stimulated cholesterol transport, and steroidogenesis: role of the peroxisome proliferator-activator receptor alpha. Endocrinology 143 2571-2583. (https://doi.org/10.1210/endo.143.7.8895)
Gray LE, Ostby J, Furr J, Price M, Veeramachaneni DN \& Parks L 2000 Perinatal exposure to the phthalates DEHP, BBP, and DINP, but not DEP, DMP, or DOTP, alters sexual differentiation of the male rat. Toxicological Sciences 58 350-365. (https://doi.org/10.1093/toxsci/58.2.350)

Gray LE, Ostby J, Furr J, Wolf CJ, Lambright C, Parks L, Veeramachaneni DN, Wilson V, Price M, Hotchkiss A et al. 2001 Effects of environmental antiandrogens on reproductive development in experimental animals. Human Reproduction Update 7 248-264. (https://doi.org/10.1093/ humupd/7.3.248)

Gray LE, Furr JR, J \& Ostby JS 2005 Hershberger assay to investigate the effects of endocrine-disrupting compounds with androgenic or antiandrogenic activity in castrate-immature male rats. Current Protocols in Toxicology 26 16.9.1-16.9.15.

Gray LE, Barlow NJ, Howdeshell KL, Ostby JS, Furr JR \& Gray CL 2009 Transgenerational effects of di (2-ethylhexyl) phthalate in the male CRL:CD(SD) rat: added value of assessing multiple offspring per litter. Toxicological Sciences 110 411-425. (https://doi.org/10.1093/toxsci/ kfp109)

Gray LE, Furr JR, Conley JM, Lambright CS, Evans N, Cardon MC, Wilson VS, Foster PM \& Hartig PC 2019 A conflicted tale of two novel $\mathrm{AR}$ antagonists in vitro and in vivo: pyrifluquinazon versus bisphenol C. Toxicological Sciences 168 632-643. (https://doi.org/10.1093/toxsci/ kfz010)

Gray LE, Furr JR, Lambright CS, Evans N, Hartig PC, Cardon MC, Wilson VS, Hotchkiss AK \& Conley JM 2020 Quantification of the uncertainties in extrapolating from in vitro androgen receptor (AR) antagonism to in vivo Hershberger assay endpoints and adverse reproductive development in male rats. Toxicological Sciences 176 297-311. (https://doi.org/10.1093/ toxsci/kfaa067)

Habert R, Muczynski V, Grisin T, Moison D, Messiaen S, Frydman R, Benachi A, Delbes G, Lambrot R, Lehraiki A et al. 2014 Concerns about the widespread use of rodent models for human risk assessments of endocrine disruptors. Reproduction 147 R119-R129. (https://doi. org/10.1530/REP-13-0497)

Hallmark N, Walker M, McKinnell C, Mahood IK, Scott H, Bayne R, Coutts S, Anderson RA, Greig I, Morris K et al. 2007 Effects of monobutyl and di(n-butyl) phthalate in vitro on steroidogenesis and Leydig cell aggregation in fetal testis explants from the rat: comparison with effects in vivo in the fetal rat and neonatal marmoset and in vitro in the human. Environmental Health Perspectives 115 390-396. (https:// doi.org/10.1289/ehp.9490)

Hannas BR, Lambright CS, Furr J, Evans N, Foster PM, Gray EL \& Wilson VS 2012 Genomic biomarkers of phthalate-induced male reproductive developmental toxicity: a targeted RT-PCR array approach for defining relative potency. Toxicological Sciences 125 544-557. (https://doi. org/10.1093/toxsci/kfr315)

Heger NE, Hall SJ, Sandrof MA, Mcdonnell EV, Hensley JB, Mcdowell EN, Martin KA, Gaido KW, Johnson KJ \& Boekelheide K 2012 Human fetal testis xenografts are resistant to phthalate-induced endocrine disruption. Environmental Health Perspectives 120 1137-1143. (https://doi. org/10.1289/ehp.1104711)

Heindel JJ, Belcher S, Flaws JA, Prins GS, Ho SM, Mao J, Patisaul HB, Ricke W, Rosenfeld CS, Soto AM et al. 2020 Data integration, analysis, and interpretation of eight academic CLARITY-BPA studies. Reproductive Toxicology 98 29-60. (https://doi.org/10.1016/j.reprotox.2020.05.014)

Hotchkiss AK, Parks-Saldutti LG, Ostby JS, Lambright C, Furr J, Vandenbergh JG \& Gray LE 2004 A mixture of the 'antiandrogens' linuron and butyl benzyl phthalate alters sexual differentiation of the male rat in a cumulative fashion. Biology of Reproduction 71 1852-1861. (https://doi.org/10.1095/biolreprod.104.031674)

Hotchkiss AK, Rider CV, Furr J, Howdeshell KL, Blystone CR, Wilson VS \& Gray LE 2010 In utero exposure to an AR antagonist plus an inhibitor of fetal testosterone synthesis induces cumulative effects on F1 male rats. Reproductive Toxicology 30 261-270. (https://doi.org/10.1016/j. reprotox.2010.06.001)

Howdeshell KL, Wilson VS, Furr J, Lambright CR, Rider CV, Blystone CR, Hotchkiss AK \& Gray LE 2008 A mixture of five phthalate esters inhibits fetal testicular testosterone production in the Sprague-Dawley rat in a cumulative, dose-additive manner. Toxicological Sciences 105 153-165. (https://doi.org/10.1093/toxsci/kfn077)

Howdeshell KL, Rider CV, Wilson VS, Furr JR, Lambright CR \& Gray LE 2015 Dose addition models based on biologically relevant reductions 
in fetal testosterone accurately predict postnatal reproductive tract alterations by a phthalate mixture in rats. Toxicological Sciences $\mathbf{1 4 8}$ 488-502. (https://doi.org/10.1093/toxsci/kfv196)

Howdeshell KL, Hotchkiss AK \& Gray LE 2017 Cumulative effects of antiandrogenic chemical mixtures and their relevance to human health risk assessment. International Journal of Hygiene and Environmental Health 220 179-188. (https://doi.org/10.1016/j.ijheh.2016.11.007)

Hurtado-Gonzalez P \& Mitchell RT 2017 Analgesic use in pregnancy and male reproductive development. Current Opinion in Endocrinology, Diabetes, and Obesity 24 225-232. (https://doi.org/10.1097/ MED.0000000000000338)

Ikezuki Y, Tsutsumi O, Takai Y, Kamet Y \& Taketani Y 2002 Determination of bisphenol A concentrations in human biological fluids reveals significant early prenatal exposure. Human Reproduction 17 2839-2841. (https:// doi.org/10.1093/humrep/17.11.2839)

Ivell R, Heng K, Nicholson H \& Anand-ivell R 2013 Brief maternal exposure of rats to the xenobiotics dibutyl phthalate or diethylstilbestrol alters adult-type Leydig cell development in male offspring. Asian Journal of Andrology 15 261-268. (https://doi.org/10.1038/aja.2012.138)

Jensen MS, Rebordosa C, Thulstrup AM, Toft G, Sorensen HT, Bonde JP, Henriksen TB \& Olsen J 2010 Maternal use of acetaminophen, ibuprofen, and acetylsalicylic acid during pregnancy and risk of cryptorchidism. Epidemiology 21 779-785. (https://doi.org/10.1097/ EDE.0b013e3181f20bed)

Jensen MS, Anand-Ivell R, Norgaard-Pedersen B, Jonsson BA, Bonde JP, Hougaard DM, Cohen A, Lindh CH, Ivell R \& Toft G 2015 Amniotic fluid phthalate levels and male fetal gonad function. Epidemiology 26 91-99. (https://doi.org/10.1097/EDE.0000000000000198)

Johnson KJ, Hensley JB, Kelso MD, Wallace DG \& Gaido KW 2007 Mapping gene expression changes in the fetal rat testis following acute dibutyl phthalate exposure defines a complex temporal cascade of responding cell types. Biology of Reproduction 77 978-989. (https://doi. org/10.1095/biolreprod.107.062950)

Johnson KJ, Heger NE \& Boekelheide K 2012 Of mice and men (and rats): phthalate-induced fetal testis endocrine disruption is species-dependent. Toxicological Sciences 129 235-248. (https://doi.org/10.1093/toxsci/ kfs206)

Jones S, Boisvert A, Francois S, Zhang L \& Culty M 2015 In utero exposure to di-(2-ethylhexyl) phthalate induces testicular effects in neonatal rats that are antagonized by genistein cotreatment. Biology of Reproduction 93 92. (https://doi.org/10.1095/biolreprod.115.129098)

Kavlock R, Barr D, Boekelheide K, Breslin W, Breysse P, Chapin R, Gaido K, Hodgson E, Marcus M, Shea K et al. 2006 NTP-CERHR expert panel update on the reproductive and developmental toxicity of di(2ethylhexyl) phthalate. Reproductive Toxicology 22 291-399. (https://doi. org/10.1016/j.reprotox.2006.04.007)

Kilcoyne KR \& Mitchell RT 2019 Effect of environmental and pharmaceutical exposures on fetal testis development and function: a systematic review of human experimental data. Human Reproduction Update 25 397-421. (https://doi.org/10.1093/humupd/dmz004)

Kilcoyne KR, Smith LB, Atanassova N, Macpherson S, McKinnell C, van den Driesche S, Jobling MS, Chambers TJ, de Gendt K, Verhoeven G et al. 2014 Fetal programming of adult Leydig cell function by androgenic effects on stem/progenitor cells. PNAS 111 E1924-E1932. (https://doi. org/10.1073/pnas.1320735111)

Kleymenova E, Swanson C, Boekelheide K \& Gaido KW 2005 Exposure in utero to di(n-butyl) phthalate alters the vimentin cytoskeleton of fetal rat Sertoli cells and disrupts Sertoli cell-gonocyte contact. Biology of Reproduction 73 482-490. (https://doi.org/10.1095/ biolreprod.104.037184)

Klinefelter GR, Laskey JW, Winnik WM, Suarez JD, Roberts NL, Strader LF, Riffle BW \& Veeramachaneni DN 2012 Novel molecular targets associated with testicular dysgenesis induced by gestational exposure to diethylhexyl phthalate in the rat: a role for estradiol. Reproduction 144 747-761. (https://doi.org/10.1530/REP-12-0266)

Koch HM, Preuss R \& Angerer J 2006 Di(2-ethylhexyl)phthalate (DEHP): human metabolism and internal exposure: an update and latest results. International Journal of Andrology 29 155-165, 181-185. (https://doi. org/10.1111/j.1365-2605.2005.00607.x)

Koopman P, Munsterberg A, Capel B, Vivian N \& Lovell-Badge R 1990 Expression of a candidate sex-determining gene during mouse testis differentiation. Nature 348 450-452. (https://doi.org/10.1038/348450a0)
Kristensen DM, Hass U, Lesne L, Lottrup G, Jacobsen PR, DesdoitsLethimonier C, Boberg J, Petersen JH, Toppari J, Jensen TK et al. 2011 Intrauterine exposure to mild analgesics is a risk factor for development of male reproductive disorders in human and rat Human Reproduction 26 235-244. (https://doi.org/10.1093/humrep/deq323)

Kuhl AJ, Ross SM \& Gaido KW 2007 CCAAT/enhancer binding protein beta, but not steroidogenic factor-1, modulates the phthalate-induced dysregulation of rat fetal testicular steroidogenesis. Endocrinology 148 5851-5864. (https://doi.org/10.1210/en.2007-0930)

Lai KP, Lee JC, Wan HT, Li JW, Wong AY, Chan TF, Oger C, Galano JM, Durand T, Leung KS et al. 2017 Effects of in utero PFOS exposure on transcriptome, lipidome, and function of mouse testis. Environmental Science and Technology 51 8782-8794. (https://doi.org/10.1021/acs. est.7b02102)

Lambrot R, Muczynski V, Lecureuil C, Angenard G, Coffigny H, Pairault C, Moison D, Frydman R, Habert R \& Rouiller-Fabre V 2009 Phthalates impair germ cell development in the human fetal testis in vitro without change in testosterone production. Environmental Health Perspectives 117 32-37. (https://doi.org/10.1289/ehp.11146)

Lara NLM, Driesche SVD, Macpherson S, Franca LR \& Sharpe RM 2017 Dibutyl phthalate induced testicular dysgenesis originates after seminiferous cord formation in rats. Scientific Reportsence Reproductive 7 2521. (https://doi.org/10.1038/s41598-017-02684-2)

Lau C, Thibodeaux JR, Hanson RG, Rogers JM, Grey BE, Stanton ME, Butenhoff JL \& Stevenson LA 2003 Exposure to perfluorooctane sulfonate during pregnancy in rat and mouse II: postnatal evaluation. Toxicological Sciences 74 382-392. (https://doi.org/10.1093/toxsci/kfg122)

Law NC, Oatley MJ \& Oatley JM 2019 Developmental kinetics and transcriptome dynamics of stem cell specification in the spermatogenic lineage. Nature Communications 10 2787. (https://doi.org/10.1038/ s41467-019-10596-0)

Lehraiki A, Racine C, Krust A, Habert R \& Levacher C 2009 Phthalates impair germ cell number in the mouse fetal testis by an androgen- and estrogen-independent mechanism. Toxicological Sciences 111 372-382. (https://doi.org/10.1093/toxsci/kfp153)

Levine $\mathrm{H}$, Jorgensen N, Martino-Andrade A, Mendiola J, Weksler-Derri D, Mindlis I, Pinotti R \& Swan SH 2017 Temporal trends in sperm count: a systematic review and meta-regression analysis. Human Reproduction Update 23 646-659. (https://doi.org/10.1093/humupd/dmx022)

Lin YT \& Capel B 2015 Cell fate commitment during mammalian sex determination. Current Opinion in Genetics and Development 32 144-152. (https://doi.org/10.1016/j.gde.2015.03.003)

Loff S, Kabs F, Witt K, Sartoris J, Mandl B, Niessen KH \& Waag KL 2000 Polyvinylchloride infusion lines expose infants to large amounts of toxic plasticizers. Journal of Pediatric Surgery 35 1775-1781.

Lottrup G, Andersson AM, Leffers H, Mortensen GK, Toppari J, Skakkebaek NE \& Main KM 2006 Possible impact of phthalates on infant reproductive health. International Journal of Andrology 29 172-181. (https://doi.org/10.1111/j.1365-2605.2005.00642.x)

Lv Y, Li L, Fang Y, Chen P, Wu S, Chen X, Ni C, Zhu Q, Huang T, Lian Q et al. 2019 In utero exposure to bisphenol A disrupts fetal testis development in rats. Environmental Pollution 246 217-224. (https://doi.org/10.1016/j. envpol.2018.12.006)

Mahood IK, Hallmark N, McKinnell C, Walker M, Fisher JS \& Sharpe RM 2005 Abnormal Leydig cell aggregation in the fetal testis of rats exposed to di (n-butyl) phthalate and its possible role in testicular dysgenesis. Endocrinology 146 613-623. (https://doi.org/10.1210/ en.2004-0671)

Mahood IK, McKinnell C, Walker M, Hallmark N, Scott H, Fisher JS, Rivas A, Hartung S, Ivell R, Mason Jl et al. 2006 Cellular origins of testicular dysgenesis in rats exposed in utero to di(n-butyl) phthalate. International Journal of Andrology 29 148-154, 181-185. (https://doi. org/10.1111/j.1365-2605.2005.00574.x)

Mahood IK, Scott HM, Brown R, Hallmark N, Walker M \& Sharpe RM 2007 In utero exposure to di(n-butyl) phthalate and testicular dysgenesis: comparison of fetal and adult end points and their dose sensitivity. Environmental Health Perspectives 115 (Supplement 1) 55-61. (https:// doi.org/10.1289/ehp.9366)

Manikkam M, Tracey R, Guerrero-Bosagna C \& Skinner MK 2012 Dioxin (TCDD) induces epigenetic transgenerational inheritance of adult onset disease and sperm epimutations. PLOS ONE 7 e46249. (https://doi. org/10.1371/journal.pone.0046249) 
Manikkam M, Tracey R, Guerrero-Bosagna C \& Skinner MK 2013 Plastics derived endocrine disruptors (BPA, DEHP and DBP) induce epigenetic transgenerational inheritance of obesity, reproductive disease and sperm epimutations. PLOS ONE 8 e55387. (https://doi.org/10.1371/journal. pone.0055387)

Matsushima A, Teramoto T, Okada H, Liu X, Tokunaga T, Kakuta Y \& Shimohigashi Y 2008 ERR gamma tethers strongly bisphenol A and 4-alpha-cumylphenol in an induced-fit manner. Biochemical and Biophysical Research Communications 373 408-413. (https://doi. org/10.1016/j.bbrc.2008.06.050)

McKinnell C, Mitchell RT, Walker M, Morris K, Kelnar CJ, Wallace WH \& Sharpe RM 2009 Effect of fetal or neonatal exposure to monobutyl phthalate (MBP) on testicular development and function in the marmoset. Human Reproduction 24 2244-2254. (https://doi.org/10.1093/humrep/ dep200)

Mehta A, Nangia AK, Dupree JM \& Smith JF 2016 Limitations and barriers in access to care for male factor infertility. Fertility and Sterility 105 1128-1137. (https://doi.org/10.1016/j.fertnstert.2016.03.023)

Meyer KB, Martino Andrade AJ, Venturelli AC, Kita DH, Machado DLB, Adams Philipsen R, Do Nascimento Silva AA, Cantao I, Moreira DL, Da Silva Junior VA et al. 2018 Identification of a critical window for ganciclovirinduced disruption of testicular development in rats. Toxicological Sciences 162 488-498. (https://doi.org/10.1093/toxsci/kfx276)

Mitchell RT, Childs AJ, Anderson RA, van den Driesche S, Saunders PT, McKinnell C, Wallace WH, Kelnar CJ \& Sharpe RM 2012 Do phthatates affect steroidogenesis by the human fetal testis? Exposure of human fetal testis xenografts to di-n-butyl phthalate. Journal of Clinical Endocrinology and Metabolism 97 E341-E348. (https://doi.org/10.1210/jc.2011-2411)

Molina-Molina JM, Amaya E, Grimaldi M, Saenz JM, Real M, Fernandez MF, Balaguer P \& Olea N 2013 In vitro study on the agonistic and antagonistic activities of bisphenol-S and other bisphenol-A congeners and derivatives via nuclear receptors. Toxicology and Applied Pharmacology 272 127-136. (https://doi.org/10.1016/j.taap.2013.05.015)

Moriyama K, Tagami T, Akamizu T, Usui T, Saijo M, Kanamoto N, Hataya Y, Shimatsu A, Kuzuya H \& Nakao K 2002 Thyroid hormone action is disrupted by bisphenol $\mathrm{A}$ as an antagonist. Journal of Clinical Endocrinology and Metabolism 87 5185-5190. (https://doi.org/10.1210/ jc.2002-020209)

Muczynski V, Cravedi JP, Lehraiki A, Levacher C, Moison D, Lecureuil C, Messiaen S, Perdu E, Frydman R, Habert R et al. 2012 Effect of mono(2-ethylhexyl) phthalate on human and mouse fetal testis: in vitro and in vivo approaches. Toxicology and Applied Pharmacology 261 97-104. (https://doi.org/10.1016/j.taap.2012.03.016)

Murphy CJ, Stermer AR \& Richburg JH 2014 Age- and Species-dependent infiltration of macrophages into the testis of rates and mice exposed to mono-(2-Ethylheyxl) phthalate (MEHP). Biology of Reproduction 9118. (https://doi.org/10.1095/biolreprod.113.115527).

Mylchreest E, Sar M, Wallace DG \& Foster PM 2002 Fetal testosterone insufficiency and abnormal proliferation of Leydig cells and gonocytes in rats exposed to di(n-butyl) phthalate. Reproductive Toxicology 16 19-28. (https://doi.org/10.1016/s0890-6238(01)00201-5)

Nel-Themaat L, Jang CW, Stewart MD, Akiyama H, Viger RS \& Behringer RR 2011 Sertoli cell behaviors in developing testis cords and postnatal seminiferous tubules of the mouse. Biology of Reproduction 84 342-350. (https://doi.org/10.1095/biolreprod.110.086900)

Nicol B \& Yao HH 2015 Gonadal identity in the absence of pro-testis factor SOX9 and pro-ovary factor beta-catenin in mice. Biology of Reproduction 93 35. (https://doi.org/10.1095/biolreprod.115.131276)

Nicol B, Grimm SA, Gruzdev A, Scott GJ, Ray MK \& Yao HH 2018 Genome-wide identification of FOXL2 binding and characterization of FOXL2 feminizing action in the fetal gonads. Human Molecular Genetics 27 4273-4287. (https://doi.org/10.1093/hmg/ddy312)

Nihi F, Moreira D, Santos Lourenco AC, Gomes C, Araujo SL, Zaia RM, Trevisani NB, de Athayde Pinto L, Moura-Costa DD, de Morais RN et al. 2014 Testicular effects following in utero exposure to the antivirals acyclovir and ganciclovir in rats. Toxicological Sciences 139 220-233. (https://doi.org/10.1093/toxsci/kfu024)

Noriega NC, Ostby J, Lambright C, Wilson VS \& Gray LE 2005 Late gestational exposure to the fungicide prochloraz delays the onset of parturition and causes reproductive malformations in male but not female rat offspring. Biology of Reproduction 72 1324-1335. (https:// doi.org/10.1095/biolreprod.104.031385)
N'Tumba-Byn T, Moison D, Lacroix M, Lecureuil C, Lesage L, Prud Homme SM, Pozzi-Gaudin S, Frydman R, Benachi A, Livera G et al. 2012 Differential effects of bisphenol A and diethylstilbestrol on human, rat and mouse fetal leydig cell function. PLOS ONE 7 e51579. (https:// doi.org/10.1371/journal.pone.0051579)

OECD 2018 Users' Handbook Supplement to the Guidance Document for Developing and Assessing Adverse Outcome Pathways. (https://doi. org/10.1787/5jlv1m9d1g32-en)

Ogunwole E, Akindele OO, Oluwole OF, Salami SA \& Raji Y 2015 Effects of oral maternal administration of caffeine on reproductive functions of male offspring of Wistar rats. Nigerian Journal of Physiological Sciences 30 51-58.

Oshida K, Vasani N, Thomas RS, Applegate D, Rosen M, Abbott B, Lau C, Guo G, Aleksunes LM, Klaassen C et al. 2015 Identification of modulators of the nuclear receptor peroxisome proliferatoractivated receptor alpha (PPARalpha) in a mouse liver gene expression compendium. PLOS ONE 10 e0112655. (https://doi.org/10.1371/ journal.pone.0112655)

Parks LG, Ostby JS, Lambright CR, Abbott BD, Klinefelter GR, Barlow NJ \& Gray LE 2000 The plasticizer diethylhexyl phthalate induces malformations by decreasing fetal testosterone synthesis during sexual differentiation in the male rat. Toxicological Sciences 58 339-349. (https://doi.org/10.1093/toxsci/58.2.339)

Passoni MT, Kristensen MN, Morais RN, Woitkowiak C, Boareto AC, Da Silva Amaral BA, Grechi N, Dalsenter PR, Munkboel CH, Styrishave B et al. 2018 Assessment of the analgesic dipyrone as a possible (anti) androgenic endocrine disruptor. Toxicology Letters 285 139-147. (https://doi.org/10.1016/j.toxlet.2017.12.021)

Pedrana G, Viotti H, Lombide P, Sanguinetti G, Pino C, Cavestany D, Sloboda DM \& MARTIN GB 2016 In utero betamethasone affects 3betahydroxysteroid dehydrogenase and inhibin-alpha immunoexpression during testis development. Journal of Developmental Origins of Health and Disease 7 342-349. (https://doi.org/10.1017/S2040174416000118)

Pettersson A, Richiardi L, Nordenskjold A, Kaijser M \& Akre O 2007 Age at surgery for undescended testis and risk of testicular cancer. New England Journal of Medicine 356 1835-1841. (https://doi.org/10.1056/ NEJMoa067588)

Radke EG, Braun JM, Meeker JD \& Cooper GS 2018 Phthalate exposure and male reproductive outcomes: a systematic review of the human epidemiological evidence. Environment International 121 764-793. (https://doi.org/10.1016/j.envint.2018.07.029)

Repouskou A, Panagiotidou E, Panagopoulou L, Bisting PL, Tuck AR, Sjödin MOD, Lindberg J, Bozas E, Rüegg J, Gennings C et al. 2019 Gestational exposure to an epidemiologically defined mixture of phthalates leads to gonadal dysfunction in mouse offspring of both sexes. Scientific Reports 9 6424. (https://doi.org/10.1038/s41598-01942377-6)

Rider CV, Furr JR, Wilson VS \& Gray LE 2010 Cumulative effects of in utero administration of mixtures of reproductive toxicants that disrupt common target tissues via diverse mechanisms of toxicity. International Journal of Andrology 33 443-462. (https://doi.org/10.1111/j.13652605.2009.01049.x)

Saffarini CM, Heger NE, Yamasaki H, Liu T, Hall SJ \& Boekelheide K 2012 Induction and persistence of abnormal testicular germ cells following gestational exposure to di-(n-butyl) phthalate in p53-null mice. Journal of Andrology 33 505-513. (https://doi.org/10.2164/ jandrol.111.013706)

Sasaki N, Okuda K, Kato T, Kakishima H, Okuma H, Abe K, Tachino H, Tuchida K \& Kubono K 2005 Salivary bisphenol-A levels detected by ELISA after restoration with composite resin. Journal of Materials Science: Materials in Medicine 16 297-300. (https://doi.org/10.1007/ s10856-005-0627-8)

Scott HM, Mason JI \& Sharpe RM 2009 Steroidogenesis in the fetal testis and its susceptibility to disruption by exogenous compounds. Endocrine Reviews 30 883-925. (https://doi.org/10.1210/er.2009-0016)

Sharpe RM 2020 Androgens and the masculinization programming window: human-rodent differences. Biochemical Society Transactions 48 1725-1735. (https://doi.org/10.1042/BST20200200)

Shono T, Kai H, Suita S \& Nawata H 2000 Time-specific effects of monon-butyl phthalate on the transabdominal descent of the testis in rat fetuses. BJU International 86 121-125. (https://doi.org/10.1046/j.1464410x.2000.00710.x) 
Shultz VD, Phillips S, Sar M, Foster PM \& Gaido KW 2001 Altered gene profiles in fetal rat testes after in utero exposure to di(n-butyl) phthalate. Toxicological Sciences 64 233-242. (https://doi.org/10.1093/ toxsci/64.2.233)

Singh S \& Singh SK 2019 Effect of gestational exposure to perfluorononanoic acid on neonatal mice testes. Journal of Applied Toxicology 39 1663-1671. (https://doi.org/10.1002/jat.3883)

Skakkebaek NE, Rajpert-de Meyts E \& Main KM 2001 Testicular dysgenesis syndrome: an increasingly common developmental disorder with environmental aspects. Human Reproduction 16 972-978. (https://doi. org/10.1093/humrep/16.5.972)

Song P, Li D, Wang X \& Zhong X 2018 Effects of perfluorooctanoic acid exposure during pregnancy on the reproduction and development of male offspring mice. Andrologia 50 e13059. (https://doi.org/10.1111/ and.13059)

Sonne SB, Kristensen DM, Novotny GW, Olesen IA, Nielsen JE, Skakkebæk NE, Rajpert-de Meyts E \& Leffers H 2008 Testicular dysgenesis syndrome and the origin of carcinoma in situ testis. International Journal of Andrology 31 275-287. (https://doi.org/10.1111/ j.1365-2605.2007.00855.x)

Spade DJ, Hall SJ, Saffarini CM, Huse SM, Mcdonnell EV \& Boekelheide K 2014 Differential response to abiraterone acetate and di-n-butyl phthalate in an androgen-sensitive human fetal testis xenograft bioassay. Toxicological Sciences 138 148-160. (https://doi.org/10.1093/toxsci/ kft266)

Spade DJ, Hall SJ, Wilson S \& Boekelheide K 2015 Di-n-butyl phthalate induces multinucleated germ cells in the rat fetal testis through a nonproliferative mechanism. Biology of Reproduction 93 110. (https:// doi.org/10.1095/biolreprod.115.131615)

Spade DJ, Bai CY, Lambright C, Conley JM, Boekelheide K \& Gray LE 2018 Validation of an automated counting procedure for phthalate-induced testicular multinucleated germ cells. Toxicology Letters 290 55-61. (https://doi.org/10.1016/j.toxlet.2018.03.018)

Spade DJ, Dere E, Hall SJ, Schorl C, Freiman RN \& Boekelheide K 2019a All-trans retinoic acid disrupts development in ex vivo cultured fetal rat testes I: altered seminiferous cord maturation and testicular cell fate. Toxicological Sciences 167 546-558. (https://doi.org/10.1093/toxsci/ kfy260)

Spade DJ, Hall SJ, Wortzel JD, Reyes G \& Boekelheide K 2019b All-trans retinoic acid disrupts development in ex vivo cultured fetal rat testes II: modulation of Mono-(2-ethylhexyl) phthalate toxicity. Toxicological Sciences 168 149-159. (https://doi.org/10.1093/toxsci/kfy283)

Stenz L, Rahban R, Prados J, Nef S \& Paoloni-Giacobino A 2019 Genetic resistance to DEHP-induced transgenerational endocrine disruption. PLoS ONE 14 e0208371. (https://doi.org/10.1371/journal.pone.0208371)

Stevant I, Neirijnck Y, Borel C, Escoffier J, Smith LB, Antonarakis SE, Dermitzakis ET \& Nef S 2018 Deciphering cell lineage specification during male sex determination with single-cell RNA sequencing. Cell Reports 22 1589-1599. (https://doi.org/10.1016/j.celrep.2018.01.043)

Stroheker T, Cabaton N, Nourdin G, Regnier JF, Lhuguenot JC \& Chagnon MC 2005 Evaluation of anti-androgenic activity of di(2-ethylhexyl)phthalate. Toxicology 208 115-121. (https://doi. org/10.1016/j.tox.2004.11.013)

Struve MF, Gaido KW, Hensley JB, Lehmann KP, Ross SM, Sochaski MA, Willson GA \& Dorman DC 2009 Reproductive toxicity and pharmacokinetics of di-n-butyl phthalate (DBP) following dietary exposure of pregnant rats. Birth Defects Research: Part B, Developmental and Reproductive Toxicology 86 345-354. (https://doi.org/10.1002/ bdrb.20199)

Szilagyi JT, Avula V \& Fry RC 2020 Perfluoroalkyl substances (PFAS) and their effects on the placenta, pregnancy, and child development: a potential mechanistic role for placental peroxisome proliferatoractivated receptors (PPARs). Current Environmental Health Reports 7 222-230. (https://doi.org/10.1007/s40572-020-00279-0)

Tainaka H, Takahashi H, Umezawa M, Tanaka H, Nishimune Y, Oshio S \& Takeda K 2012 Evaluation of the testicular toxicity of prenatal exposure to bisphenol A based on microarray analysis combined with $\mathrm{MeSH}$ annotation. Journal of Toxicological Sciences 37 539-548. (https://doi. org/10.2131/jts.37.539)

Tartarin P, Moison D, Guibert E, Dupont J, Habert R, Rouiller-Fabre V, Frydman N, Pozzi S, Frydman R, Lecureuil C et al. 2012 Metformin exposure affects human and mouse fetal testicular cells. Human Reproduction 27 3304-3314. (https://doi.org/10.1093/humrep/des264)

Thibodeaux JR, Hanson RG, Rogers JM, Grey BE, Barbee BD, Richards JH, Butenhoff JL, Stevenson LA \& Lau C 2003 Exposure to perfluorooctane sulfonate during pregnancy in rat and mouse. I: maternal and prenatal evaluations. Toxicological Sciences 74 369-381. (https://doi. org/10.1093/toxsci/kfg121)

Thompson CJ, Ross SM \& Gaido KW 2004 Di(n-butyl) phthalate impairs cholesterol transport and steroidogenesis in the fetal rat testis through a rapid and reversible mechanism. Endocrinology 145 1227-1237. (https://doi.org/10.1210/en.2003-1475)

Thompson CJ, Ross SM, Hensley J, Liu K, Heinze SC, Young SS \& Gaido KW 2005 Differential steroidogenic gene expression in the fetal adrenal gland versus the testis and rapid and dynamic response of the fetal testis to di(n-butyl) phthalate. Biology of Reproduction 73 908-917. (https:// doi.org/10.1095/biolreprod.105.042382)

Toppari J, Kaleva M \& Virtanen HE 2001 Trends in the incidence of cryptorchidism and hypospadias, and methodological limitations of registry-based data. Human Reproduction Update 7 282-286. (https:// doi.org/10.1093/humupd/7.3.282)

Ungewitter E, Rotgers E, Bantukul T, Kawakami Y, Kissling GE \& Yao HH 2017 From the cover: teratogenic effects of in utero exposure to di-(2ethylhexyl)-phthalate (DEHP) in B6:129S4 mice. Toxicological Sciences 157 8-19. (https://doi.org/10.1093/toxsci/kfx019)

van den Driesche S, Kolovos P, Platts S, Drake AJ \& Sharpe RM 2012a Inter-relationship between testicular dysgenesis and Leydig cell function in the masculinization programming window in the rat. PLOS ONE 7 e30111. (https://doi.org/10.1371/journal.pone.0030111)

van den Driesche $S$, Walker $M$, McKinnell $C$, Scott HM, Eddie SL, Mitchell RT, Seckl JR, Drake AJ, Smith LB, Anderson RA et al. $2012 b$ Proposed role for COUP-TFII in regulating fetal Leydig cell steroidogenesis, perturbation of which leads to masculinization disorders in rodents. PLOS ONE 7 e37064. (https://doi.org/10.1371/ journal.pone.0037064)

van den Driesche S, McKinnell C, Calarrao A, Kennedy L, Hutchison GR, Hrabalkova L, Jobling MS, Macpherson S, Anderson RA, Sharpe RM et al. 2015 Comparative effects of di(n-butyl) phthalate exposure on fetal germ cell development in the rat and in human fetal testis xenografts. Environmental Health Perspectives 123 223-230. (https:// doi.org/10.1289/ehp.1408248)

van den Driesche S, Kilcoyne KR, Wagner I, Rebourcet D, Boyle A, Mitchell R, McKinnell C, Macpherson S, Donat R, Shukla CJ et al. 2017 Experimentally induced testicular dysgenesis syndrome originates in the masculinization programming window. JCI Insight 2 e91204. (https:// doi.org/10.1172/jci.insight.91204)

Vandenberg LN, Hauser R, Marcus M, Olea N \& Welshons WV 2007 Human exposure to bisphenol A (BPA). Reproductive Toxicology 24 139-177. (https://doi.org/10.1016/j.reprotox.2007.07.010)

Varga T, Czimmerer Z \& Nagy L 2011 PPARs are a unique set of fatty acid regulated transcription factors controlling both lipid metabolism and inflammation. Biochimica et Biophysica Acta 1812 1007-1022. (https:// doi.org/10.1016/j.bbadis.2011.02.014)

Veeramachaneni DN \& Klinefelter GR 2014 Phthalate-induced pathology in the foetal testis involves more than decreased testosterone production. Reproduction 147 435-442. (https://doi.org/10.1530/REP13-0441)

Veroniki AA, Cogo E, Rios P, Straus SE, Finkelstein Y, Kealey R, Reynen E, Soobiah C, Thavorn K, Hutton B et al. 2017 Comparative safety of antiepileptic drugs during pregnancy: a systematic review and network meta-analysis of congenital malformations and prenatal outcomes. BMC Medicine 15 95. (https://doi.org/10.1186/s12916-017-0845-1)

Virtanen I, Lohi J, Tani T, Korhonen M, Burgeson RE, Lehto VP \& Leivo I 1997 Distinct changes in the laminin composition of basement membranes in human seminiferous tubules during development and degeneration. American Journal of Pathology 150 1421-1431.

Walker C, Ghazisaeidi S, Collet B, Boisvert A \& Culty M 2020 In utero exposure to low doses of genistein and di-(2-ethylhexyl) phthalate (DEHP) alters innate immune cells in neonatal and adult rat testes. Andrology 8 943-964. (https://doi.org/10.1111/andr.12840)

Wang Y, Liu W, Yang Q, Yu M \& Zhang Z 2015 Di (2-ethylhexyl) phthalate exposure during pregnancy disturbs temporal sex determination 
regulation in mice offspring. Toxicology 336 10-16. (https://doi. org/10.1016/j.tox.2015.07.009)

Ward JM, Peters JM, Perella CM \& Gonzalez FJ 1998 Receptor and nonreceptor-mediated organ-specific toxicity of di(2-ethylhexyl) phthalate (DEHP) in peroxisome proliferator-activated receptor $\alpha$ null mice. Toxicologic Pathology 26 240-246. (https://doi. org/10.1177/019262339802600208)

Welsh M, Saunders PTK, Fisken M, Scott HM, Hutchison GR, Smith LB \& Sharpe RM 2008 Identification in rats of a programming window for reproductive tract masculinization, disruption of which leads to hypospadias and cryptorchidism. Journal of Clinical Investigation 118 1479-1490. (https://doi.org/10.1172/JCl34241)

Whorton D, Krauss RM, Marshall S \& Milby TH 1977 Infertility in male pesticide workers. Lancet 2 1259-1261. (https://doi.org/10.1016/s01406736(77)92665-4)

Williams C, Bondesson M, Krementsov DN \& Teuscher C 2014 Gestational bisphenol A exposure and testis development. Endocrine Disruptors 2 e29088. (https://doi.org/10.4161/endo.29088)

Wilson VS, Lambright C, Furr J, Ostby J, Wood C, Held G \& Gray LE 2004 Phthalate ester-induced gubernacular lesions are associated with reduced insl3 gene expression in the fetal rat testis. Toxicology Letters 146 207-215. (https://doi.org/10.1016/j.toxlet.2003.09.012)

Wilson VS, Blystone CR, Hotchkiss AK, Rider CV \& Gray LE 2008 Diverse mechanisms of anti-androgen action: impact on male rat reproductive tract development. International Journal of Andrology 31 178-187. (https://doi.org/10.1111/j.1365-2605.2007.00861.x)

Yavetz H, Harash B, Paz G, Yogev L, Jaffa AJ, Lessing JB \& Homonnai ZT 1992 Cryptorchidism: incidence and sperm quality in infertile men. Andrologia 24 293-297. (https://doi.org/10.1111/j.1439-0272.1992. tb02655.x)

Zhang H, Lu H, Chen P, Chen X, Sun C, Ge RS, Su Z \& Ye L 2020 Effects of gestational perfluorooctane sulfonate exposure on the developments of fetal and adult Leydig cells in F1 males. Environmental Pollution 262 114241. (https://doi.org/10.1016/j.envpol.2020.114241)

Zhao B, Li L, Liu J, Li H, Zhang C, Han P, Zhang Y, Yuan X, Ge RS \& Chu Y 2014 Exposure to perfluorooctane sulfonate in utero reduces testosterone production in rat fetal Leydig cells. PLOS ONE 9 e78888. (https://doi.org/10.1371/journal.pone.0078888)

Received 2 November 2020

First decision 4 January 2021

Revised manuscript received 2 July 2021

Accepted 27 July 2021 